\title{
Evaluation of groundwater quality for drinking and irrigation purposes using GIS-based water quality index in urban area of Abaya-Chemo sub-basin of Great Rift Valley, Ethiopia
}

\author{
Tamru Tesseme Aragaw ${ }^{1}$. Gopalakrishnan Gnanachandrasamy $y^{2,3}$
}

Received: 2 February 2021 / Accepted: 6 August 2021 / Published online: 13 August 2021

(C) The Author(s) 2021

\begin{abstract}
Groundwater is the major resource for drinking and irrigation purposes in urban areas of Abaya-Chemo sub-basin of Great Rift Valley, Ethiopia. There is an incredible increase in demand in the sub-basin for good-quality groundwater resources. However, the exhaustive irrigation and rapid urbanization has posed a serious threat to groundwater quality in the urban districts of sub-basin like Arba Minch town. The aim of the study was to evaluate the groundwater quality status and to map their spatial distribution with respect to the suitability for drinking and irrigation purposes in Arba Minch town, Ethiopia. Fourteen bore well samples were examined for geochemical variations and groundwater qualities. The spatial distribution maps of quality parameters were prepared using the kriging method in ArcGIS 10.3. Drinking water quality index, sodium adsorption ratio (SAR), percentage sodium ( $\mathrm{Na} \%$ ), residual sodium carbonate (RSC), and permeability index (PI) were considered for drinking and irrigation suitability assessment. Comparison of the hydrochemical results with the World Health Organization (WHO) and Ethiopian drinking water standards (ES) and various classifications revealed that the current status of the groundwaters is suitable for drinking and irrigation purposes except for a few sites at the northwestern part of the study area. The WQI results revealed that $7 \%$ and $64 \%$ of samples fall from excellent to good classes for drinking categories. Irrigation indices also demonstrated that $80 \%$ of samples fall in good classes for irrigation purposes. About 75 percent of samples belong to $\mathrm{Ca}-\mathrm{Mg}-\mathrm{HCO}_{3}$ facies, and the reaming samples belong to $\mathrm{Ca}-\mathrm{Mg}-\mathrm{Cl}$ facies. The results of the study concluded that the proposed approach is reliable and efficient for the groundwater pollution status evaluation and can also be applied in decision making for effective groundwater resources monitoring in the study area.
\end{abstract}

Keywords Groundwater quality · GIS · Drinking and irrigation water suitability · Abaya-Chemo sub-basin · Great Rift Valley $\cdot$ Ethiopia

\section{Introduction}

Groundwater is a vital underlying resource for the local community existence and economic development in semiarid and arid countries like Ethiopia. Recent studies have revealed

Gopalakrishnan Gnanachandrasamy

tamruiit@gmail.com

1 Faculty of Water Supply and Environmental Engineering, Arba Minch Water Technology Institute, Arba Minch University, Arba Minch, Ethiopia

2 School of Geography and Planning, Sun Yat - Sen University, Guangzhou 510275, People's Republic of China

3 Center for Earth, Environment \& Resources, Sun Yat - Sen University, Guangzhou 510275, People's Republic of China that the country has about 124 billion cubic meters (BCM) of river water, $70 \mathrm{BCM}$ lake water, and $30 \mathrm{BCM}$ groundwater resources (Berhanu et al. 2014). However, the groundwater covers more than $90 \%$ of potable drinking water sources in the country due mostly to it is the lowest cost water-supply option in the place where rainfall and surface water flows become more irregular (Adimalla et al. 2020). In the face of this, several studies have been carried out in developing countries such as India (Ponsadailakshmi 2018), China (Zhou et al. 2021), Ghana (Boateng et al. 2016), and Iran (Abbasnia et al. 2019), which showed that natural and anthropogenic sources can pollute and deteriorate suitability of the groundwater quality for drinking and irrigation purposes.

Under this consideration, the groundwater quality assessment is essential to utilize resources optimally and

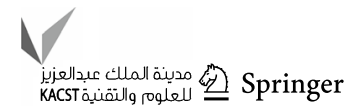


sustainable manner in the Abaya-Chemo sub-basin of Great Rift valley, Ethiopia. Contamination in ground water quality has become one of the most serious problems in the world for the last few decades (Yousefi et al. 2018). It is most likely due to very hard to stop the pollution and restore the deteriorated quality, once the groundwater is contaminated. Changes in the quality of the groundwater are most likely due to the rock-water interface and oxidation-reduction reactions while the water travels in the aquifers (Abd ElAziz 2017; Saleem et al. 2016). Besides, point and non-point source of pollutants and water-borne pathogens which are percolated in the recharge area are the major source of the groundwater quality deterioration parameters (Ismail et al. 2020; Mishra et al. 2018).

In view of this, the quality of groundwater has need equally attention to its quantity because of high quality of water is need for domestic and irrigation consumption (Yousefi et al. 2018). In the last three decades, there has been an incredible increase in the demand for groundwater exploitation in the urban areas of the Abaya-Chemo sub-basin because of the rapid population growth and the accelerated pace of development. The overexploitation of the groundwater and anthropogenic activities such as urban sewage, industrial and agricultural expansion are some of the main reasons that can affect the groundwater quality in the urban areas of the sub-basin (Adimalla et al. 2018; Rawat et al. 2019). The contamination of the groundwater does not only affect quality but also threatens human health, economic development as well as social wealth (Gupta 2020; Roy et al. 2018). Thus, regular monitoring of the groundwater quality becomes imperative and devise options and means to preserve it (Bawoke and Anteneh 2020).

Therefore, monitoring of quality is very important for sustainable management of the groundwater for various purposes particularly in the area where the groundwater abstraction and excessive subsurface contaminant load from improper disposal of urban wastewater and solid waste dumping are inadequately controlled (Ahamad et al. 2019; Rana et al. 2018). Traditional approaches to evaluate the groundwater quality has been based on the compression of experimentally determined geochemical values with the existing specified standards and guidelines (Ponsadailakshmi et al. 2018). The presence of physicochemical and microbiological parameters in the water above or below the existing standard limit can lead to failure in the water quality (Beyene et al. 2019; Tomas et al. 2017). In fact, this comparative quality assessment approach allows for proper identification of pollutant sources and may be vital for checking legal compliance. However, it does not readily provide an overall insight into the spatial and temporal trends in the water quality status of the studied systems and does not offer a valuable tool for reliable water resources management (Bhunia et al. 2018).
The hydrogeochemical water quality assessment has made it very easy to offer a better understanding of the water quality of the groundwater for various uses by a systematic summary of complex data matrices (Zhou et al. 2020). Groundwater quality data indicate significant evidence to the geological history and suggestions of the groundwater recharge, discharge, and storage (Esmeray and Gökcekli 2020; Mahaqi et al. 2018). Further, it permits the identification of possible sources which influence the groundwater resources and offers a promising tool for a rapid solution to contamination problems. It is, therefore, the geochemical investigation is a promising tool to recognize these processes that are accountable for the possible changes in the quality of the groundwater.

Despite the fact that in the urban areas of the AbayaChemo sub-basin, Ethiopia, the groundwater possessions are most significant resources for several uses, there was no water quality monitoring system, no aquifer and wellhead protection zones for the quality protection across the sub-basin, particularly in Arba Minch town, Ethiopia. Under these circumstances, hydrochemical characteristics and detailed assessment of spatial suitability quality of the groundwater for drinking and irrigation usages can provide an early warning system before high cleanup cost is required (Mallick et al. 2021; Verma et al. 2020; Zhou et al. 2020). Moreover, the water quality index (WQI) as a means to numerically summarize set of measured multiple water quality parameters into a single value, which shows the composite influence of significant parameters of the water quality situations. Thus, WQI can be applied as a reliable tool to assess spatially and temporal variations in the overall quality of the groundwater.

To date, no hydrogeochemical studies have been carried out in Arba Minch, Ethiopia, to evaluate the hydrochemistry and assess the spatial distribution of quality of the groundwater. It is, therefore, a comprehensive investigation is essential to identify the hydrogeochemical characteristics that disturb groundwater suitability for various purposes. The aim of the present study is to identify the hydrogeochemical and evaluate the groundwater quality suitability for drinking and irrigation purposes. The study also demonstrates the spatial distribution of the major water chemistry using IDW interpolation in GIS.

\section{Material and methods}

\section{Study area and hydrogeology}

Arba Minch is a district and fast-growing town in Southern Ethiopia which is far about $500 \mathrm{~km}$ south of Addis Ababa, capital of Ethiopia, located at the base of the AbayaChemo sub-basin of Great Rift Valley with an elevation 
of $1285 \mathrm{~m}$ above sea level (Fig. 1). The town got its name from the plentiful springs (forty springs) that feed the groundwater forest and the Kulfo river, which flows from northwest to southeast direction in the town and drains to lake Chemo. The study area is made up of two town centers, the uptown administrative center of Secha and $4 \mathrm{~km}$ away from the downtown commercial and residential area of Sikela, which are connected by a paved road. Based on the 2017 census report of CSA (2007), the town has a total population of 200,373. Arba Minch is well known as a source of fruit including banana, manage, and, pineapple and is also known for its fish farms. The climate of the study area is typically arid and semiarid with two distinct seasons. The mean annual rainfall is approximately about $818 \mathrm{~mm}$, and the rainfall distribution is irregular in space and time. Most likely, the precipitation in the study area is concentrated from April to May and September to October of each year. The hot season of the year is from June to August and from November to March, and its annual average temperature is about $22{ }^{\circ} \mathrm{C}$. The groundwater in the study province happens mostly as shallow depth aquifers with water level depths of less than $10 \mathrm{~m}$ below the ground level. The water supply in the study area is delivered through pipe networks and overhead tanks. The abundant local springs which produce a groundwater forest are the main sources of water supply in the town, and recently some tube wells are also used as a supplementary water source for the residents.

Geologically, the study area is part of the Main Ethiopian Rift (MER) valley system in the south segment that has been subjected for complex geological structures. The geology of the study area is a complex of both igneous rocks and alluvial deposits (Fig. 2), the south west and the central parts of the study area are predominantly covered by well differentiated Lacustrine deposited of silt, sand, clay and gravel. Along the Kulfo river and northern part of the study area is comprised of volcanic rocks and alluvial sediments. Groundwater occurrence, availability and movement condition of the study area is directly related to the presence of water bearing geological units and some structures. Generally, the most water bearing formation in the study area is thick alluvial section with primary porosity and highly fractured and weathered trap basalt. The course alluvial materials deposited at the lower depths could be another source of groundwater potential in the area.

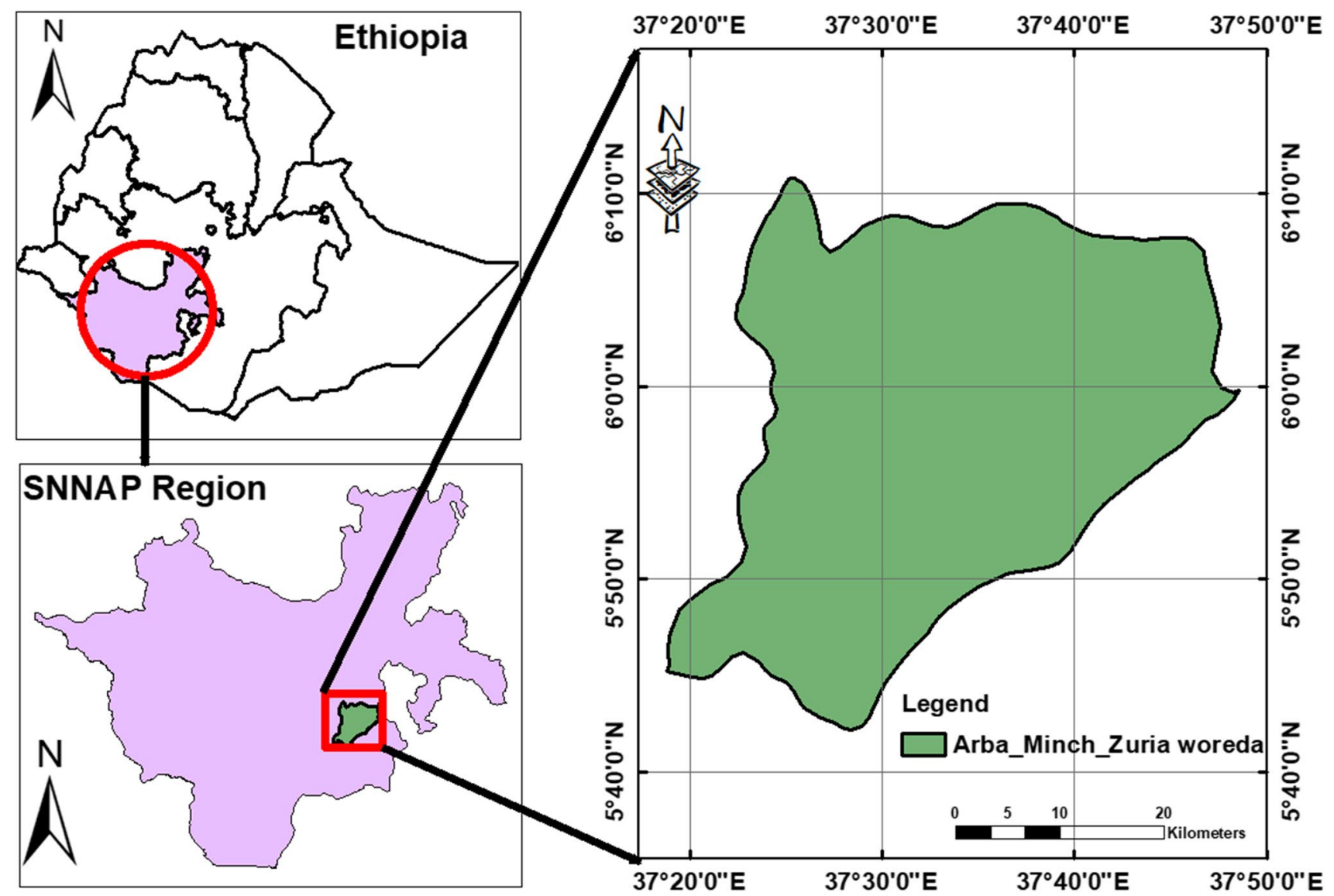

Fig. 1 Map of the study area 


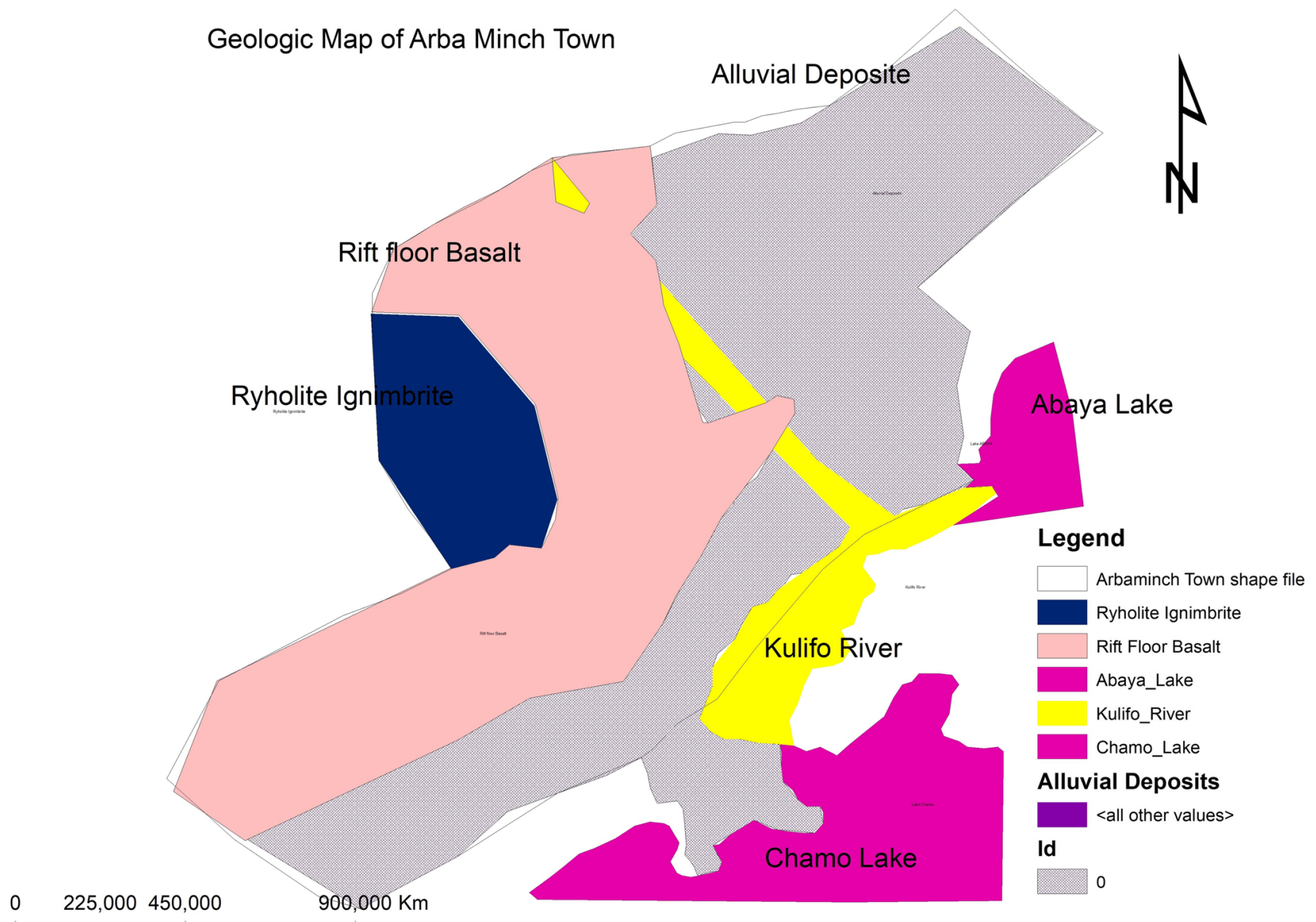

Fig. 2 Geological map of the study area

\section{Sampling and analysis}

A total of fourteen water samples were collected in August 2020 in tight-capped high-quality polyethylene bottles. Among these samples, thirteen tapping wells and a spring water sample were obtained in Arba Minch town. The location of sampling points was determined using a global positioning system (GPS) (Model: GPS map 76 CSx), and its details are presented in Table 1 . The density of the wells is slightly higher in university zones (northwestern) than in southern and central zones of the study area (Fig. 3). Sampling containers were well washed with distilled water and thoroughly rinsed with the sample water to be taken for analysis before sampling. The groundwater samples were collected after pumping for 10-15 min until constant conductivity was reached. This was carried out to remove stagnant water in the well. The variables namely $\mathrm{pH}$ and EC were measured in situ by a handheld $\mathrm{pH}$ and EC meter (HANNA HI-9828, USA). The collected water samples were kept in iceboxes (at $4{ }^{\circ} \mathrm{C}$ ) and then transported to the laboratory for further physicochemical analysis as per the
Table 1 Locations of the groundwater sampling in the study area

\begin{tabular}{lll}
\hline S.No & Geographical locations & \\
\cline { 2 - 3 } & Northing & Easting \\
\hline S-1 & $06^{\circ} 00^{\prime} 45.1^{\prime \prime}$ & $37^{\circ} 33^{\prime} 19.59^{\prime \prime}$ \\
S-2 & $06^{\circ} 00^{\prime} 13.84^{\prime \prime}$ & $37^{\circ} 33^{\prime} 20.29^{\prime \prime}$ \\
S-3 & $06^{\circ} 01^{\prime} 58.55^{\prime \prime}$ & $37^{\circ} 33^{\prime} 29.61^{\prime \prime}$ \\
S-4 & $06^{\circ} 02^{\prime} 44.59^{\prime \prime}$ & $37^{\circ} 33^{\prime} 24.03^{\prime \prime}$ \\
S-5 & $06^{\circ} 02^{\prime} 30.29^{\prime \prime}$ & $37^{\circ} 33^{\prime} 41.87^{\prime \prime}$ \\
S-6 & $06^{\circ} 02^{\prime} 43.3^{\prime}$ & $37^{\circ} 33^{\prime} 41.87^{\prime \prime}$ \\
S-7 & $06^{\circ} 02^{\prime} 40.69^{\prime \prime}$ & $37^{\circ} 33^{\prime} 44.02^{\prime \prime}$ \\
S-8 & $06^{\circ} 02^{\prime} 21.25^{\prime \prime}$ & $37^{\circ} 34^{\prime} 21.2^{\prime \prime}$ \\
S-9 & $06^{\circ} 03^{\prime} 52.89^{\prime \prime}$ & $37^{\circ} 33^{\prime} 49.09^{\prime \prime}$ \\
S-10 & $06^{\circ} 03^{\prime} 41.44^{\prime}$ & $37^{\circ} 33^{\prime} 40.29^{\prime \prime}$ \\
S-11 & $06^{\circ} 03^{\prime} 36.8^{\prime \prime}$ & $37^{\circ} 33^{\prime} 38.54^{\prime \prime}$ \\
S-12 & $06^{\circ} 04^{\prime} 03.1^{\prime \prime}$ & $37^{\circ} 33^{\prime} 49.16^{\prime \prime}$ \\
S-13 & $06^{\circ} 04^{\prime} 16.71^{\prime \prime}$ & $37^{\circ} 33^{\prime} 52.94^{\prime \prime}$ \\
S-14 & $06^{\circ} 03^{\prime} 52.89^{\prime \prime}$ & $37^{\circ} 33^{\prime} 49.09^{\prime \prime}$ \\
\hline
\end{tabular}




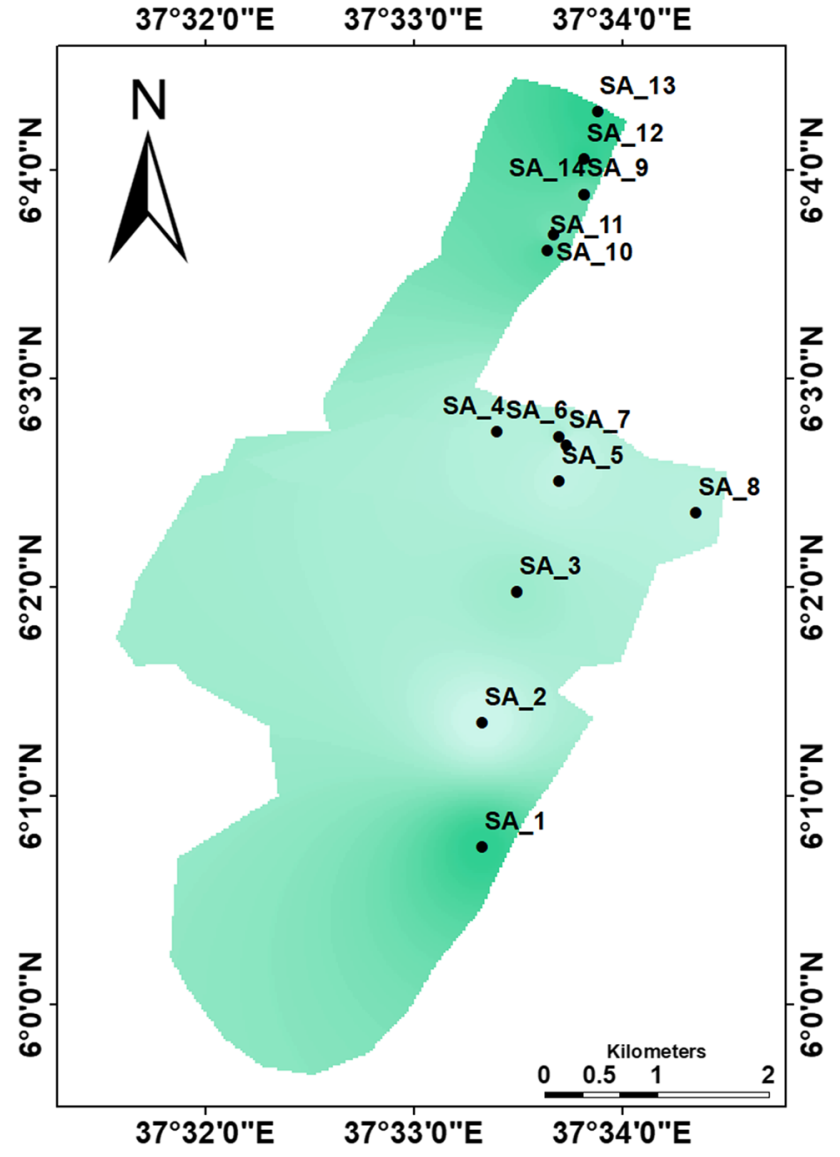

Fig. 3 Groundwater samples location map of the study area

methods prescribed in the American Public Health Association manual APHA (2005).

Major cations namely the value of sodium $\left(\mathrm{Na}^{+}\right)$and potassium $\left(\mathrm{K}^{+}\right)$were determined by using dual channel flame photometer (model-2655-10). The value of magnesium $\left(\mathrm{Mg}^{+2}\right)$, calcium $\left(\mathrm{Ca}^{+2}\right)$ and total hardness was analyzed using the EDTA titration method. Correspondingly, the anions such as the concentration of bicarbonate $\left(\mathrm{HCO}_{3}^{-}\right)$ and carbonate $\left(\mathrm{CO}_{3}^{-}\right)$and alkalinity analysis were carried out using acid-base titration. The value of chloride $\left(\mathrm{Cl}^{-}\right)$ concentration was determined by silver nitrate $\left(\mathrm{AgNO}_{3}\right)$ titration. The chemical constituent fluoride was determined by the SPADNS spectrometric method. The concentration of sulfates was determined using a gravimetric method. The concentration of TDS was determined by weight and drying at $103-105^{\circ} \mathrm{C}$ in the oven. The concentration of orthophosphate $\left(\mathrm{PO}_{4}{ }^{-2}\right)$ was determined by spectrophotometer method with acid molybdate. The nitrate was determined using the cadmium column reduction method. The accuracy of the analysis for major ions was crosschecked by taking the relationship between the total cations $\left(\mathrm{Ca}^{+2}, \mathrm{Mg}^{+2}, \mathrm{Na}^{+}\right.$and $\left.\mathrm{K}^{+}\right)$ and total anions $\left(\mathrm{PO}_{4}{ }^{-3}, \mathrm{NO}_{3}{ }^{-}, \mathrm{SO}_{4}{ }^{-2}, \mathrm{CO}_{3}{ }^{-2}, \mathrm{HCO}_{3}{ }^{-}\right.$and $\mathrm{Cl}^{-}$) for each of the water samples. The ionic charge balance was computed using equation (Domenico and Schwartz 1990; Mahlknecht et al. 2017) as given:

$E=\frac{\sum \text { cations }-\sum \text { anions }}{\sum \text { cations }+\sum \text { anions }} \times 100$

where $\mathrm{E}$ is the error percent/reaction error; cations and anions are the sum of the total cations and total anions expressed in milliequivalents per liter.

The computed value of ion balance errors is less than the accepted limit of $\pm 10 \%$, an added proof of the precision of the data, whereas $\mathrm{E}$ greater than $10 \%$ was eliminated from the subsequent analyses.

\section{Results and discussion}

The descriptive statistical summary of analyzed parameters of the groundwater samples in the study area is given in Table 2. The drinking water standards of the World Health Organization WHO (2017) and Ethiopian standard ES (2003) are shown in Table 2. The spatial distribution map of major ions $\left(\mathrm{Ca}^{+2}, \mathrm{Mg}^{+2}, \mathrm{Na}^{+}, \mathrm{K}^{+}, \mathrm{HCO}_{3}{ }^{-}, \mathrm{SO}_{4}{ }^{-2}, \mathrm{Cl}^{-}\right.$, $\mathrm{NO}_{3}{ }^{-} ; \mathrm{F}^{-} ; \mathrm{PO}_{4}{ }^{-2}$ ) of the groundwater samples in the study region are created and discussed herein.

\section{Major chemical analysis}

\section{Total dissolved solids}

Estimation of the total dissolved solids (TDS) is very essential to understand the status of the contaminants present in the groundwater. The suitability of groundwater with the TDS value of less than about $600 \mathrm{mg} / \mathrm{L}$ is often considered to be good, whereas the TDS level greater than about $1000 \mathrm{mg} / \mathrm{L}$ is not acceptable for drinking and increasing unpalatable WHO (2017). The maximum TDS was recorded at BH-9 with $672.9 \mathrm{mg} / \mathrm{L}$, and the lowest value is $138.8 \mathrm{mg} / \mathrm{L}$ at BH-5 with an average value of $319.5 \mathrm{mg} / \mathrm{L}$ in all samples of the groundwater (Table 2). Thus, the samples in the study area were classified from desirable to permissible for drinking purposes as per the groundwater classification of Davis and De Wiest (1966) (Table 3). These values indicated that a low content of soluble salts in the groundwater samples which can be used for drinking without any health risk. The TDS zonation map (Fig. 4a) shows that the values of the TDS increased from south to northwestern which could be due to anthropogenic factors and geological characteristics of the aquifer in the district of the study area. Further, high TDS might be due to higher residence time of groundwater in contact with the aquifer body. 
Table 2 Descriptive analysis results of the groundwater samples in the study area

\begin{tabular}{|c|c|c|c|c|c|c|c|c|}
\hline \multirow[t]{2}{*}{ Parameters } & \multirow[t]{2}{*}{ Mean } & \multirow[t]{2}{*}{ Minimum } & \multirow[t]{2}{*}{ Maximum } & \multirow[t]{2}{*}{ Range } & \multirow[t]{2}{*}{ St.Dev } & \multirow[t]{2}{*}{ Variance } & \multicolumn{2}{|c|}{ Drinking water standards } \\
\hline & & & & & & & WHO (2017) & ES (2003) \\
\hline $\mathrm{pH}$ & 7.72 & 7.15 & 7.98 & 0.83 & 0.24 & 0.056 & $6.5-8.5$ & $6.5-8.5$ \\
\hline TDS & 319.5 & 138.8 & 688.0 & 549 & 194.1 & $38,045.9$ & 500 & 1000 \\
\hline $\mathrm{EC}$ & 607.1 & 290.0 & 1382 & 1092 & 340.4 & $115,883.7$ & 1500 & 1500 \\
\hline $\mathrm{Na}^{+2}$ & 61.2 & 11 & 156.6 & 145.6 & 54.5 & 2969.1 & 200 & 200 \\
\hline $\mathrm{K}^{+}$ & 1.75 & 1 & 4.1 & 3.1 & 0.76 & 0.581 & 12 & 12 \\
\hline $\mathrm{Ca}^{+2}$ & 18.69 & 10.42 & 32.06 & 21.64 & 5.71 & 32.63 & 75 & 200 \\
\hline $\mathrm{Mg}^{+2}$ & 25.57 & 11.08 & 46.16 & 35.08 & 10.71 & 114.61 & 50 & 150 \\
\hline $\mathrm{HCO}_{3}^{-}$ & 266.3 & 128 & 528 & 400 & 131.1 & $17,188.2$ & 120 & $\mathrm{Na}^{*}$ \\
\hline $\mathrm{Cl}^{-}$ & 54.0 & 18 & 120 & 102.0 & 34.75 & 1207.38 & 250 & 600 \\
\hline $\mathrm{SO}_{4}^{-2}$ & 149.4 & 10.60 & 303.8 & 293.21 & 110.2 & $12,142.3$ & 250 & 500 \\
\hline $\mathrm{PO}_{4}^{-2}$ & 0.22 & 0.00 & 0.46 & 0.46 & 0.13 & 0.0173 & $\mathrm{Na}^{*}$ & $\mathrm{Na}^{*}$ \\
\hline $\mathrm{F}^{-}$ & 0.24 & 0.02 & 0.60 & 0.58 & 0.15 & 0.024 & 1.5 & 1.5 \\
\hline $\mathrm{NO}_{3}^{-}$ & 35.81 & 3.6 & 53.30 & 49.70 & 16.17 & 261.37 & 11 & 45 \\
\hline Hardness & 136.4 & 65.6 & 198 & 132.4 & 40.2 & 1614.5 & 500 & 500 \\
\hline Alkalinity & 293.4 & 156 & 552 & 396 & 134.6 & $18,106.1$ & 500 & $\mathrm{Na}^{*}$ \\
\hline
\end{tabular}

Note: units in $\mathrm{mg} / \mathrm{L}$ except for $\mathrm{pH}$ (unitless) and $\mathrm{EC}(\mu \mathrm{S} / \mathrm{cm})$; $\mathrm{Na}^{*}$ means the value is not specified; St.Dev stand for standard deviation

\begin{tabular}{lllll}
\hline TDS (mg/l) & Classification & Sample numbers & $\begin{array}{l}\text { Number of } \\
\text { samples }\end{array}$ & \% of samples \\
\hline$<500$ & Desirable for drinking & $1-8$ and $10-12$ & 11 & 78.57 \\
$500-1,000$ & Permissible for drinking & 9,13 and 14 & 3 & 21.43 \\
$<3,000$ & Useful for irrigation & & 0 & 100 \\
$>3,000$ & Unfit for drinking and irrigation & & 0 & \\
Total & & & 14 & 100 \\
\hline
\end{tabular}

Table 3 The groundwater classification of Davis and De Wiest (1966)

\section{Electrical conductivity (EC)}

The value of $\mathrm{pH}$ is one of the most significant operational parameters to determine the pollution status of the groundwater quality. Although it has no direct effect on human health, it controls the quantity and chemical structure of a number of organic and inorganic matters which dissolved in the groundwater. The highest $\mathrm{pH}(7.98 \mathrm{mg} / \mathrm{L})$ was measured at BH-7 and the lowest is 7.15 at BH-1, with an average value of 7.22 in all the groundwater samples of the study area (Table 2). Obtained results revealed that the groundwater samples of the study area were slightly alkaline in nature. As far as drinking purpose is concerned, as presented in the distribution map (Fig. 4b), all the samples fall within the desirable limit for drinking consumption. The permissible limit of $\mathrm{pH}$ value for drinking water quality is between 6.5 and 8.5 as per WHO guideline WHO (2017) and Ethiopian Standard ES (2003).
Electrical conductivity is often used to measure an ability to conduct electric current through the dissolved salts that exist in the groundwater, providing information on the enrichment of dissolved salt content in the groundwater. The presence of an excess quantity of charged particles limited the quality of groundwater desirability for drinking and irrigation uses. The maximum desirable limit of EC for human consumption is restricted to about $1,500 \mu \mathrm{m} / \mathrm{cm}$ as per (WHO 2017; ES 2003). The maximum EC value was measured at BH-9 with $1060 \mu \mathrm{m} / \mathrm{cm}$ and the lowest is $290 \mu \mathrm{m} / \mathrm{cm}$ at BH-5, with an average value of $607.1 \mu \mathrm{m} / \mathrm{cm}$ in the groundwater samples of the study area (Table 2). Classification based on EC value (Table 4), the groundwater samples in the study area have been found in the range of low to medium enrichments of salts in nature as per Freeze and Cherry (1979). However, relatively higher EC values have been observed 

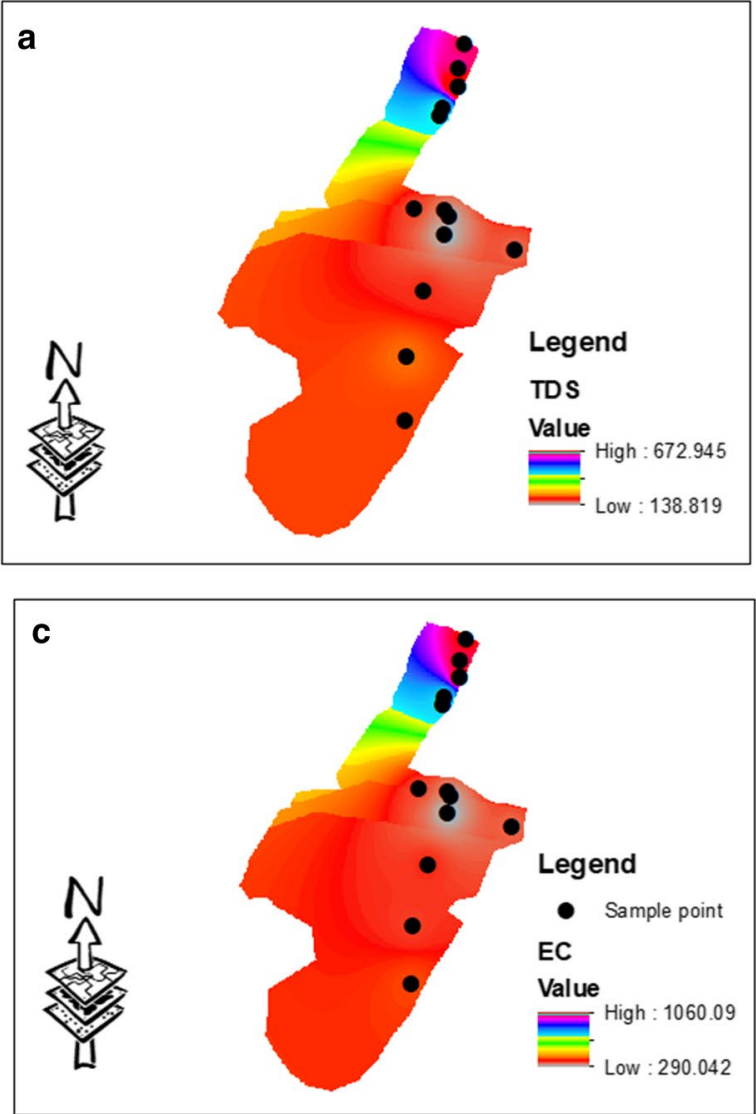

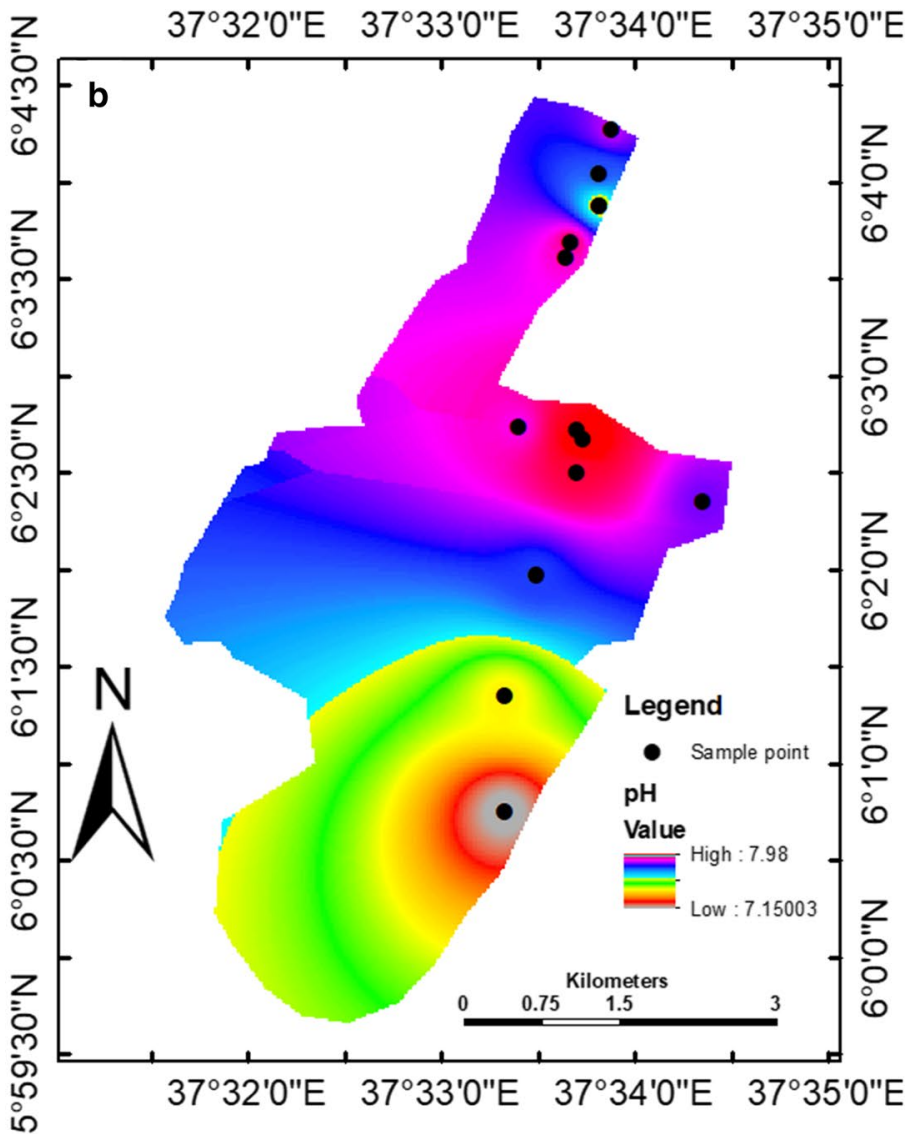

Fig. 4 The spatial variation map:a TDS, $\mathbf{b} \mathrm{pH}$, and $\mathbf{c}$ EC in the groundwater samples

Table 4 Classified drinking water based on Electrical conductivity values

\begin{tabular}{lllll}
\hline $\begin{array}{l}\text { Electrical conduc- } \\
\text { tivity }(\mu \mathrm{S} / \mathrm{cm})\end{array}$ & Classification & Sample numbers & $\begin{array}{l}\text { Number of } \\
\text { samples }\end{array}$ & \% of samples \\
\hline$<1,500$ & Permissible for drinking & $1-14$ & 14 & 100 \\
$1,500-3,000$ & Not permissible for drinking & & 0 & 0 \\
$>3,000$ & Hazardous & & 0 & 0 \\
Total & & 14 & 100 \\
\hline
\end{tabular}

in northwestern and some central areas of the study region, which indicated high enrichment of salts in the locations (Fig. 4c). The high EC values might be due to anthropogenic sources such as extensive agricultural activity and improper waste discharged in the region.

\section{Chloride concentration}

Chlorides are a widely distributed element in natural water because of weathering, sedimentary rocks and soils, discharging of wastewaters from domestic and industrial as well as the municipality. Groundwater with high chloride concentration can cause a salty taste to water and beverages, while the excess of $250 \mathrm{mg} / \mathrm{L}$ gives an increase to a noticeable taste in water (WHO 2017). Further, a high concentration of chloride may also cause harm to heart and kidney diseases of humans, and also corrosion is affected in water distribution systems. The highest chloride ion concentration is measured $120 \mathrm{mg} / \mathrm{L}$ at BH-14 and the lowest value is $18 \mathrm{mg} / \mathrm{L}$ at BH-2, with a mean value of $54 \mathrm{mg} / \mathrm{L}$ (Table 2) in the groundwater of the study area. The groundwater samples located in the present study region (Table 2) fall within the prescribed limits $(250 \mathrm{mg} / \mathrm{L})$ for safe drinking water as per WHO (2017) and ES (2003) standard. The spatial distribution map of chloride concentration (Fig. 5a) revealed that the groundwater samples near the river and in the northwestern part of the study areas were susceptible to chloride 

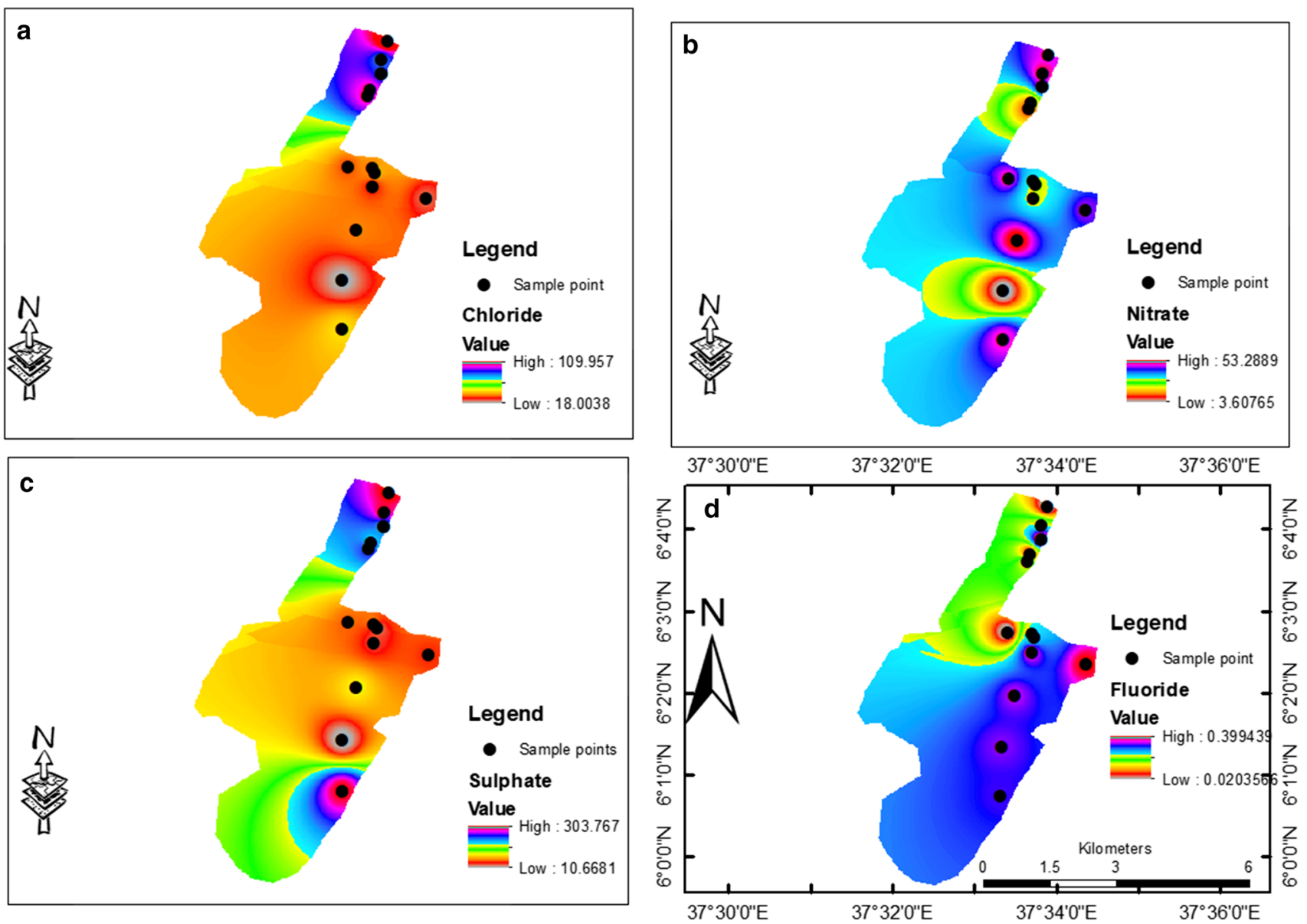

Fig. 5 The spatial variation map: a chloride, $\mathbf{b}$ nitrate $\mathbf{c}$ sulfate and $\mathbf{d}$ fluoride in the groundwater samples

contamination. These relatively higher chloride concentrations in the groundwater samples could be probably due to rock and soil weathering and the leaching of the constituents from sewerages and agrochemicals from nearby farmlands.

\section{Nitrate concentration}

Nitrate in the groundwater is commonly derived from excessive consumption of fertilizers in agricultural land and contamination from human or animal wastes as a consequence of the oxidation of ammonia and identical sources. The maximum nitrate value was obtained at BH-3 with $53.3 \mathrm{mg} / \mathrm{L}$ and the lowest is 3.6 at BH-2, with an average value of $35.30 \mathrm{mg} / \mathrm{L}$ in the groundwater of the study area (Table 2). The nitrate concentration except in the groundwater samples of BHs-1, 2, 3, 4, and BHs12-14 fall within a safe zone from nitrate contamination as the desirable limit of $45 \mathrm{mg} / \mathrm{l}$ for drinking water as per WHO (2017) and ES (2003) norms (Fig. 5b). Correspondingly, these particular groundwater samples were under the threat of nitrate contamination which results in human health risk and deteriorates the quality of the groundwater. A high concentration of nitrate in drinking water is poisonous and causes blue baby syndrome in children, diabetes, and gastric carcinomas because of the production of nitrosamide and nitrosamine in the human body. An extensively irrigated and excess application of inorganic nitrogenous fertilizers could be the source of the high concentration of nitrates in the groundwaters. These high nitrate values could also be caused by leaching from the wrong siting of the community traditional pit lateness and septic tanks as well as improper storage of the animal manures.

\section{Sulphate concentration}

Determination of sulfate concentration is very important for evaluating natural groundwater quality for drinking and irrigation purposes. The presence of sulfate in drinking groundwater can source for obvious taste. It may also unstable when its concentration exceeds the WHO (2017) standard level (400 mg/L) and cause a laxative impact on human health with the excess magnesium in the groundwater. The highest concentration of sulfate $(303.8 \mathrm{mg} / \mathrm{L})$ 
was recorded in BH-13 and the lowest is $10.6 \mathrm{mg} / \mathrm{L}$ at BH-2, with an average value of $149.4 \mathrm{mg} / \mathrm{L}$ in all samples of groundwater (Table 2). The obtained results demonstrated that the majority of samples $(80 \%)$ fall below the allowable limits prescribed for drinking purposes at levels of $250 \mathrm{mg} / \mathrm{L}$ by WHO (2017) and ES (2003) standard except $\mathrm{BH}-1,9,12$, and13. The high values of sulfate in the northwestern part of the study area as presented in the spatial distribution map (Fig. 5c) could be derived from gypsum dissolution and other human influences. Groundwater with a high concentration of chloride and sulfate could affect the corrosion phenomenon and water distribution network systems (Lakshmanan 2003).

\section{Phosphate $\left(\mathrm{PO}_{4}{ }^{-2}\right)$}

In the study area, the value of $\mathrm{PO}_{4}{ }^{-2}$ ranged from 0 to 0.64 with an average value of $0.24 \mathrm{mg} / \mathrm{L}$ (Table 2). These results showed the addition of phosphate by the breakdown of organic matters of weathered rocks, phosphate leaching, from fertilizers, and other human influences. The leading anion nutrients in the groundwater of the study area are in the following order $\mathrm{SO}_{4}{ }^{-2}>\mathrm{Cl}^{-}>\mathrm{NO}_{3}{ }^{-}>$and $\mathrm{PO}_{4}{ }^{-2}$ (Fig. 4d). The presence of an alkaline environment may enhance the solubility of silica concentration in the groundwater samples, and it shows the secondary impact of silicate weathering.

\section{Fluoride concentration}

Fluoride is an extensively distributed element in rocks and exists in the form of fluorides in a number of minerals. It is a very vital element for humans because taking less quantity of fluoride in drinking water lower than about $0.6 \mathrm{mg} / \mathrm{L}$ donates tooth caries. Further, excess concentration of fluoride in groundwater may cause dental and skeletal fluorosis. The values of fluoride in the study area varied from 0.02 to $0.60 \mathrm{mg} / \mathrm{L}$, with an average of $0.24 \mathrm{mg} / \mathrm{L}$ (Table 2). The spatial map (Fig. 5d) shows that fluoride ion concentrations in all samples fall within the permissible levels. The maximum recommended limit of fluoride is given to be $1.5 \mathrm{mg} / \mathrm{l}$ by WHO (2017). Thus, all examined groundwater samples showed suitability for drinking without posing any health risk. The concentration of magnesium $\left(\mathrm{Ca}^{+2}\right)$ is a higher in samples containing higher concentration of fluoride. It was most likely due to the higher solubility of magnesium fluoride than that of the calcium fluoride in the groundwater of the study area.

\section{Bicarbonate $\left(\mathrm{HCO}_{3}^{-}\right)$}

The bicarbonate is a very important anion particularly in irrigation water as regards calcium and a lesser degree to magnesium. It controls the sodium hazard due to it brings about a change in soluble sodium percentage in irrigation water. In the groundwater of the study area, the highest bicarbonate concentration $(528 \mathrm{mg} / \mathrm{l})$ was recorded at $\mathrm{BH}-12$ and the lowest is $128 \mathrm{mg} / \mathrm{L}$ at BH-7, with an average value of $266.3 \mathrm{mg} / \mathrm{L}$ in the groundwater samples of the study area (Table 2). The result demonstrated that $99.14 \%$ of the samples fall within suitable for irrigation. According to the spatial distribution map of bicarbonate in the study area (Fig. 6a), all samples were under the permissible limit of WHO (2017) except for sample of BH-12 with $528 \mathrm{mg} / \mathrm{L}$. These variations displayed those northwestern parts were prone to bicarbonate hazards (Fig. 6a). The higher concentration of $\mathrm{HCO}_{3}{ }^{-}$in the water points to the dominance of mineral dissolution (Stumm and Morgan 1981).

\section{Alkalinity}

Alkalinity is one of the vital water quality parameters that can be used to measure the capacity of neutralized acids. The highest value of alkalinity in samples of the study area is about $552 \mathrm{mg} / \mathrm{L}$ at BH-12, whereas the lowest value is about $156 \mathrm{mg} / \mathrm{L}$ at BH-2 (Table 2). The values of alkalinity in the southern part of the study region fall within the permissible limit that are being prescribed in WHO (2017) and ES (2003) for drinking water. As the spatial distribution map (Fig. 6b) shows, the values of the alkalinity increased in the northwestern part of the study area. These high alkalinity values might be attributed due to contribution from carbonate lithology. This indicated that the anthropogenic sources are more in northern and northwestern parts of the study region which were prone to bicarbonate hazard.

\section{Total hardness}

Water hardness $(\mathrm{TH})$ is mostly caused by the existence in water of cations, namely calcium and magnesium, and of anions such as carbonate, bicarbonate, chloride, and sulfate. It is often indicated by precipitation of soap scum and requires for additional use of soap to accomplish cleaning. The hardness value in sampled waters ranged from 65.5 to $198 \mathrm{mg} / \mathrm{L}$ with an average value of $136.4 \mathrm{mg} / \mathrm{L}$ (Table 2). Based on the grading standards of $\mathrm{TH}\left(\right.$ as $\left.\mathrm{CaCO}_{3}\right)$ (Table 5), the groundwater samples of the study area were delineated from soft to hard water category. Safe desired limit of

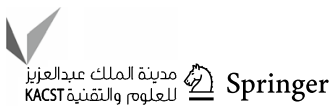



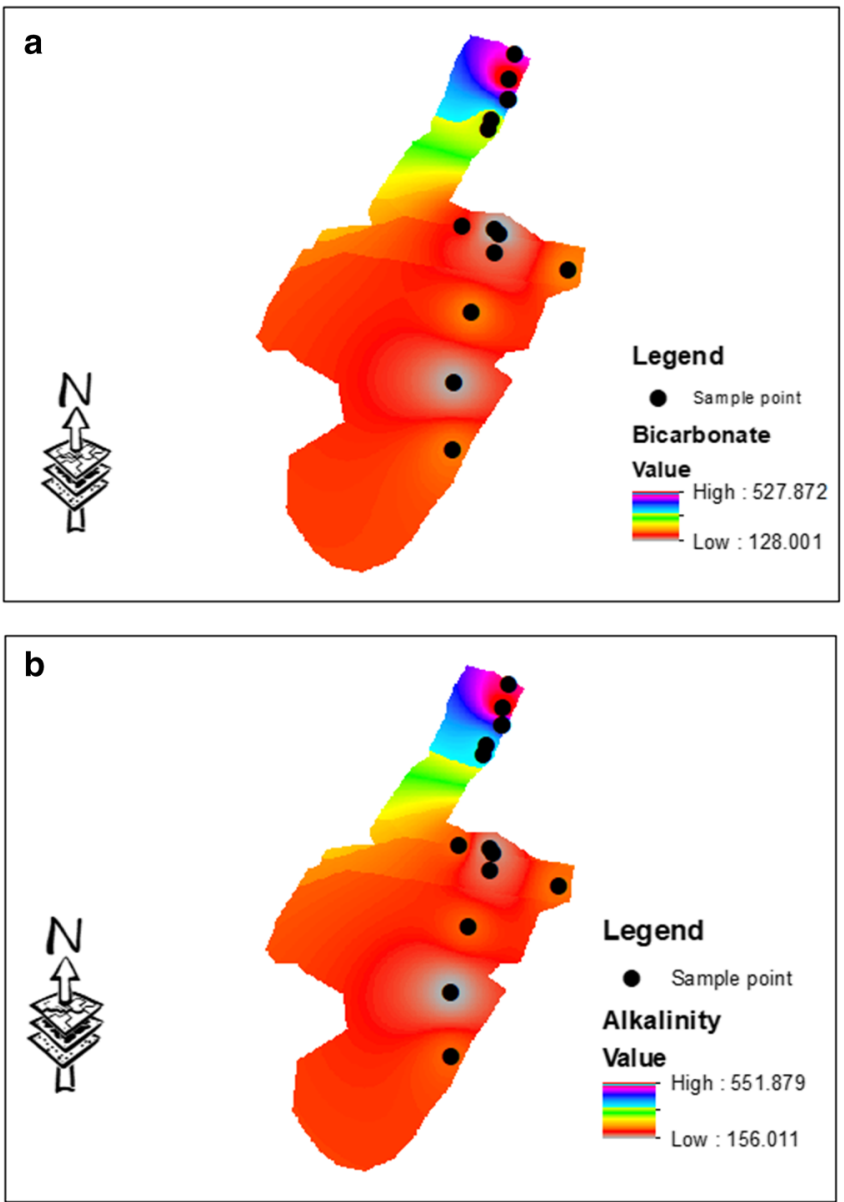

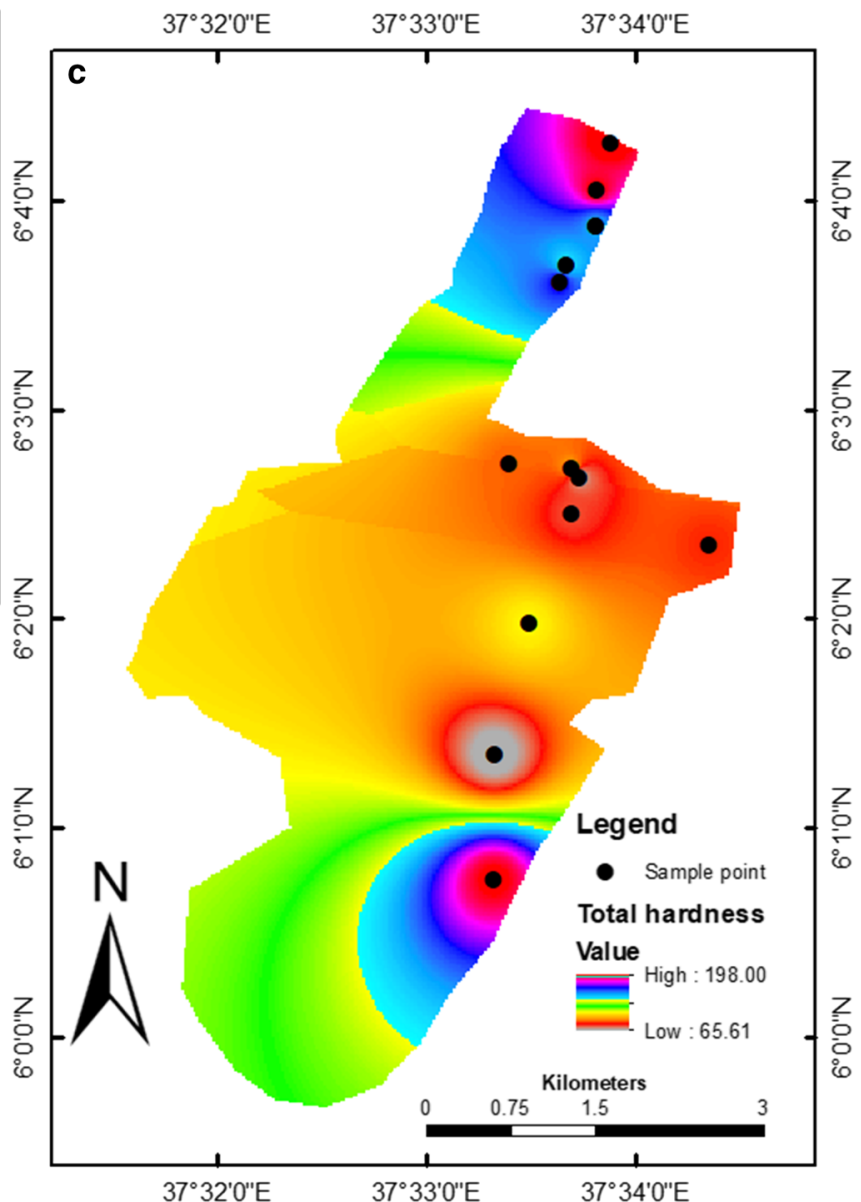

Fig. 6 The spatial variation map: a bicarbonates $\mathbf{b}$ alkalinity and $\mathbf{c}$ total hardness

hardness is recommended about $500 \mathrm{mg} / \mathrm{L}$, and the maximum permissible limit is about $1000 \mathrm{mg} / \mathrm{L}$ as per WHO (2017) and ES (2003) standards. The spatial map of TH (Fig. 6c) indicates that the water in the northwestern part of the present study site falls in the moderately high to hard water category, which shows deteriorating groundwater quality situations for drinking purposes. It might be attributed due to weathering of limestone, sedimentary rock and calcium bearing minerals. The presence of TH about $200 \mathrm{mg} / \mathrm{L}$

Table 5 The grading standards of total hardness

\begin{tabular}{lllll}
\hline $\begin{array}{l}\mathrm{TH} \\
(\mathrm{mg} / \mathrm{l} \text { as }\end{array}$ & Classification & $\begin{array}{l}\text { Sample num- } \\
\text { bers }\end{array}$ & $\begin{array}{l}\text { Number } \\
\text { of sam- } \\
\text { ples }\end{array}$ & \% of samples \\
\hline$<75$ & Soft & 1 & 1 & 7.1 \\
$75-150$ & $\begin{array}{c}\text { Moderately } \\
\text { high }\end{array}$ & $\begin{array}{c}3,4-8,12 \text { and } \\
\text { (15 }\end{array}$ & 8 & 57.1 \\
$<300$ & Hard & $1,9-11$ and 13 & 5 & 35.8 \\
$>3,000$ & Very hard & & 0 & \\
Total & & & 14 & 100 \\
\hline
\end{tabular}

at samples of BH-9 and 10 with high value of $\mathrm{pH}$ and alkalinity scale deposition was easily observed in water distribution systems, tanks in the student building of the main campus of Arba Minch university. It has also been detected by extract soap consumption for washing clothes and subsequent scam formation in water tankers of the university staff residents. However, hard water is generally believed to have no significant harmful effect on human health.

\section{Calcium and magnesium ( $\mathrm{Ca}$ and $\mathrm{Mg}$ )}

Calcium and magnesium are the most plentiful elements in natural water and found mostly as bicarbonates compounds and also in the form of sulfate and chloride. The concentrations of calcium and magnesium should be determined to evaluate the suitability of the groundwater for human consumption. The shortage of magnesium and calcium are usually associated with magnified risks to humans, namely hypertension, osteoporosis, vasoconstrictions, atherosclerotic vascular disease, etc. On the other hand, drinking 
groundwater with high content of calcium and magnesium should be eliminated in the case of kidney stones or bladder stones. The calcium concentrations in the groundwater samples varied from 14.43 to $32.06 \mathrm{mg} / \mathrm{L}$, with an average concentration of $18.69 \mathrm{mg} / \mathrm{L}$ (Table 2). Relatively, the higher calcium concentration is observed to be $32.06 \mathrm{mg} / \mathrm{L}$ at groundwater sample BH-11 (Fig. 7a). This high calcium might be due to the dissolution of precipitates of $\mathrm{CaCO}_{3}$ and $\mathrm{CaMg}\left(\mathrm{CO}_{3}\right)_{2}$ during the groundwater recharge. The maximum allowable limit of calcium concentration for drinking water is stated as $75 \mathrm{mg} / \mathrm{L}$ (Domenico and Schwartz 1990). The calcium value at all samples falling below the permissible limits is being prescribed in WHO (2017) and ES (2003) for drinking water. In the case of the magnesium, the maximum concentration is $46.16 \mathrm{mg} / \mathrm{L}$ at BH-10 and the lowest is 11.08 at BH-5, with an average value of $25.56 \mathrm{mg} / \mathrm{L}$ in all groundwater samples of the study area (Table 2). The maximum desirable limit of magnesium concentration for human consumption is $100 \mathrm{mg} / \mathrm{L}$ as ES (2003) and $150 \mathrm{mg} / \mathrm{l}$ WHO (2017). As per the spatial map of magnesium, all the samples in the study region that fall under the desirable limits are given (WHO, 2017) for drinking water (Fig. 7b). A relatively higher concentration of magnesium ions in the groundwater samples compared with the concentration of calcium ions is mostly due to weathering of magnesium minerals and leaching of dolomites.

\section{Sodium}

Sodium is a common element that is distributed widely in freshwater and positions sixth among the elements in order of abundance. The abundance of sodium in groundwater mostly depends on the related anions and the temperature of the solution. The maximum sodium concentration $(156.6 \mathrm{mg} / \mathrm{L})$ was measured at $\mathrm{BH}-12$, at the northwestern region of the study area, and the minimum $(11 \mathrm{mg} / \mathrm{L})$ is at BH-2, with a mean of $61.21 \mathrm{mg} / \mathrm{L}$ in the groundwater samples of the study area (Table 2). High sodium concentration northwestern region could be due to silicate weathering and halite dissolution as well as overexploitation of the region by urbanization (the presence of higher educational institutes).
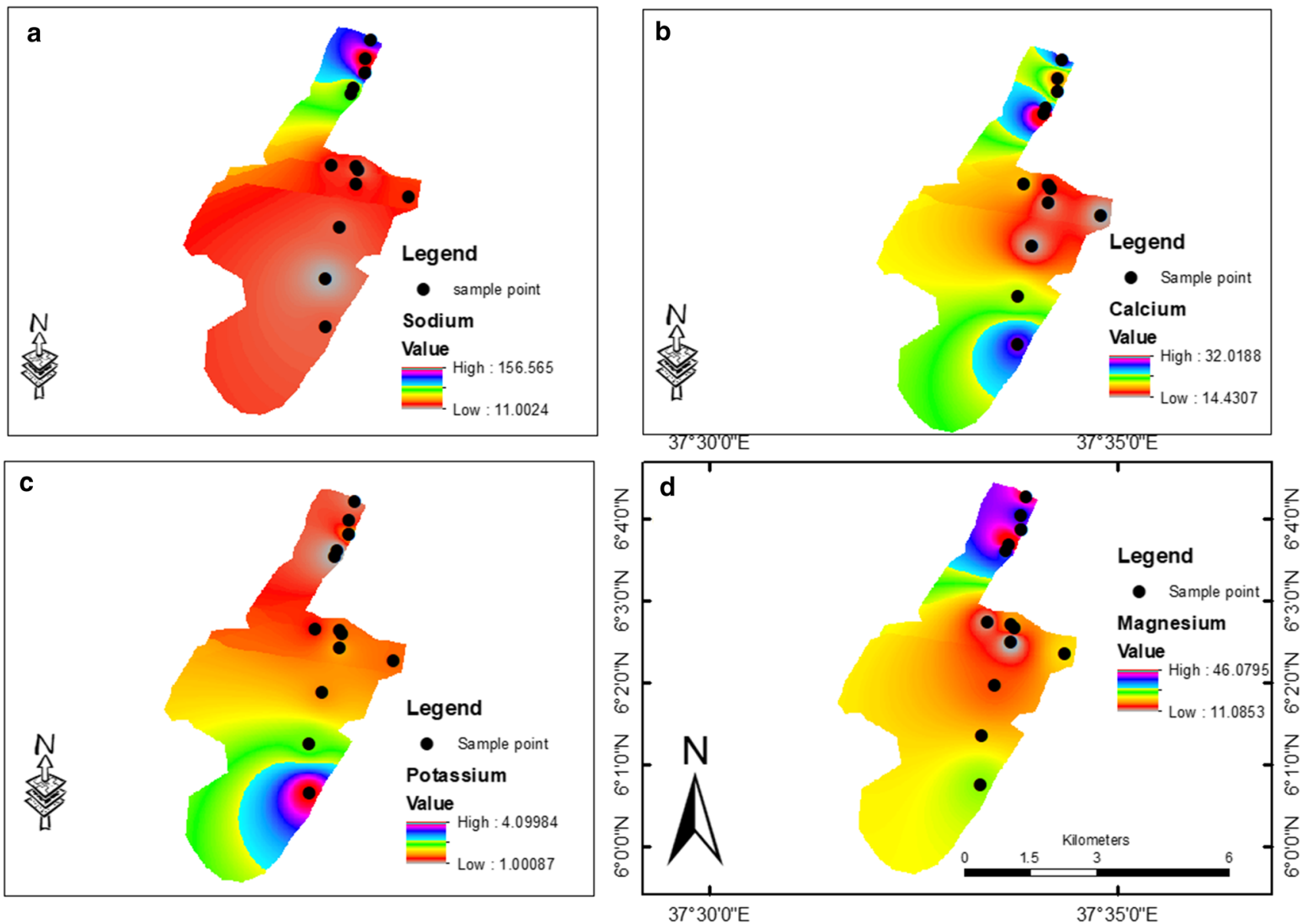

Fig. 7 The spatial variation of map: a calcium $\mathbf{b}$ magnesium $\mathbf{c}$ sodium and $\mathbf{d}$ potassium 
All samples except samples at BH-9, 12, 13 and 14 the concentration of sodium was lower than $100 \mathrm{mg} / \mathrm{L}$ in all samples which are located in the south and central part of the study area (Fig. 7c).

\section{Potassium}

Potassium is one of the most important elements in freshwater for healthy humans, and it is found in lower quantity compared with $\mathrm{Ca}, \mathrm{Mg}$ and $\mathrm{Na}$. The minimum and maximum concentrations of potassium in the groundwater samples of the study area varied from 1.0 to $4.1 \mathrm{mg} / \mathrm{L}$ with an average of $1.75 \mathrm{mg} / \mathrm{L}$ (Table 2). Accordingly, WHO (2017) and ES (2003) suggest the maximum permissible limit of potassium in the drinking water is $12 \mathrm{mg} / \mathrm{L}$. As the spatial distribution map of potassium (Fig. 7d) revealed that $100 \%$ of samples in the study region fall below the permissible limit of WHO (2017) (Table 2). A relatively lower concentration of potassium concentration was observed compared with sodium in the study region. It is most likely due to the high resistance of potash feldspars to chemical weathering in the present study area.

\section{Water quality index for drinking purposes (WQI)}

Water quality index (WQI) can be devised as a reliable technique for assessment and rating the groundwater quality for drinking purposes. Since WQI had been proposed initially by Horton, a subsequent modification has been made by several researchers such as Brown et al. (1970) and Backman et al. (2006). The WQI is a weighted summation of the major parameters in drinking water in light of certain defined national and World Health Organization guideline objectives. In this regard, WQI was computed at three stages in the present study. In the first stage, twelve water quality parameters (TDS, $\mathrm{pH}, \mathrm{HCO}_{3}{ }^{-}, \mathrm{Cl}^{-}, \mathrm{SO}_{4}{ }^{-2}, \mathrm{NO}_{3}{ }^{-}, \mathrm{F}^{-}$, $\mathrm{TH}$, $\mathrm{Ca}^{+2}, \mathrm{Mg}^{+2}, \mathrm{Na}^{+}$, and $\mathrm{K}^{+}$) were selected based on their corresponding importance in defining water quality with respect of human consumption. The weight $\left(\mathrm{w}_{\mathrm{i}}\right)$ was assigned for selected geochemical parameters based on the comparative importance of the parameters in the overall groundwater quality assessments for drinking purposes. The assigned weight value for the parameters ranged from 1 to 5 based on their perceived effects on primary human health. The maximum weight was given to those parameters which have a significant human health risk and based on their occurrence above certain critical concentration could limit the serviceability of the groundwater for drinking purposes. The maximum weight of 5 was offered to the parameters, namely TDS, $\mathrm{NO}_{3}$, and $\mathrm{Cl}^{-}$, on the basis of their importance in water quality evaluation for drinking usage, whereas the minimum weight of 1 was assigned to the variable such as $\mathrm{HCO}_{3}{ }^{-}$due to its relatively less significant role in water quality assessment as presented in Table 6 . Numbers from 1 to 4 were assigned to the remaining parameters such as calcium, sodium, magnesium, $\mathrm{pH}$, fluoride, sulfate, and total hardness on the basis of their importance proposed by WQI. On this rule, 4, 3, 2, and 1 show very high, high, average, and little importance correspondingly in overall QWI computation. In the second step, the relative weight $\left(\mathrm{W}_{\mathrm{i}}\right)$ was calculated using Eq. (2). The value of weight $\left(\mathrm{w}_{\mathrm{i}}\right)$ and the corresponding computed relative weight $\left(\mathrm{W}_{\mathrm{i}}\right)$ and $\mathrm{WHO}$ standard for each parameter are presented in Table 3.

$W_{i}=\frac{w_{i}}{\sum_{i=1}^{n} w_{i}}$

where $\mathrm{W}_{\mathrm{i}}$ is relative weight, $\mathrm{w}_{\mathrm{i}}$ is weight of each parameter, and $\mathrm{n}$ is the number of parameters.

In the third step, the quality rating scale $\left(\mathrm{q}_{\mathrm{i}}\right)$ for each parameter was computed by dividing concentration of the parameter in each water sample to its respective standard value has been given by either WHO (2017) and ES (2003) and then finally multiplied the results by 100 (Eq. 3):

$q_{i}=\left(\frac{C_{i}}{S_{i}}\right) \times 100$

where $q_{i}$ is quality rating and $C_{i}$ is the concentration of each parameter in each water sample in milligrams per liter. $S_{i}$ is the drinking water standard for each chemical parameter in milligrams per liter according to the guidelines of the WHO (2017) and ES (2003).

Lastly, the sub-index for each parameter was computed by first determined the $\mathrm{SI}_{i}$ for each geochemical parameter and then used to determine the WQI as per Eqs. (4) and (5):

Table 6 Drinking water quality standards of WHO (2017) with assigned weights for quality parameters

\begin{tabular}{lllll}
\hline Parameter & $\begin{array}{l}\text { WHO } \\
\text { standards } \\
(\mathrm{mg} / \mathrm{L})\end{array}$ & $\begin{array}{l}\text { Most } \\
\text { desirable } \\
\text { limits }\end{array}$ & $\begin{array}{l}\text { WHO maximum } \\
\text { allowable limits }\end{array}$ & Weight (wi) \\
\hline $\mathrm{pH}$ & $6.5-8.5$ & 8.5 & 3 & 0.073 \\
$\mathrm{TDS}$ & 500 & 1500 & 5 & 0.122 \\
$\mathrm{TH}$ & 300 & 300 & 3 & 0.073 \\
$\mathrm{HCO}_{3}{ }^{-}$ & 120 & 120 & 3 & 0.073 \\
$\mathrm{SO}_{4}^{-2}$ & 250 & 400 & 3 & 0.073 \\
$\mathrm{Cl}^{-}$ & 250 & 600 & 4 & 0.098 \\
$\mathrm{NO}_{3}^{-}$ & 11 & 45 & 5 & 0.122 \\
$\mathrm{~F}^{-}$ & 1.5 & 1.5 & 5 & 0.122 \\
$\mathrm{Ca}^{+2}$ & 75 & 200 & 3 & 0.073 \\
$\mathrm{Mg}^{+2}$ & 50 & 150 & 3 & 0.073 \\
$\mathrm{Na}^{+}$ & 200 & 200 & 2 & 0.049 \\
$\mathrm{~K}^{+}$ & 12 & 12 & 2 & 0.049 \\
& & Sum & 41 & 1 \\
\hline
\end{tabular}


$S I_{i}=w_{i} \times q_{i}$

$W Q I=\sum S I_{i}$

where $\mathrm{SI}_{\mathrm{i}}$ is the sub-index of ith parameter, $\mathrm{q}_{\mathrm{i}}$ is the rating based on concentration of ith parameter, and $n$ is the number of parameters.

The calculated WQI values are often categorized into five classes (Table 7), namely excellent, good, poor, very poor, and unsuitable for human consumption.

\section{Drinking water quality index (DWQI)}

The water quality index (WQI) was computed to determine the suitability of groundwater quality for drinking purposes. Table 7 shows the computed value of WQI in the sampling of groundwater in the study area. The WQI value in the samples of the study area varied from 29.30 to 120.29. According to DWQI classification (Table 7), that $7 \%$ of groundwaters were classified under the "excellent" class, $64 \%$ under the "good" class, $29 \%$ as a "poor" class, and $0 \%$ as a "very poor". The DWQI distribution map (Table 7) revealed in all groundwater samples in the study can be used for safe drinking. However, the few samples in the northwestern part of the study area were found not suitable for drinking. This worst condition is due to the indiscriminate practice of agrochemicals and fertilizers at farmland area as well as improper domestic waste disposal.

Table 7 Water quality index (WQI) classification for individual samples

\begin{tabular}{lrll}
\hline Sample & \multicolumn{1}{c}{ WQI } & Class of WQI & Remarks \\
\hline BH-1 & 98.18 & Good water & Excellent: WQI $<50$ \\
BH-2 & 29.31 & Excellent & Good: $50<$ QWI $<99.99$ \\
BH-3 & 95.50 & Good water & Poor: $100<$ QWI $<199.99$ \\
BH-4 & 85.47 & Good water & Very poor:200 $<$ QWI $<299.9$ \\
BH-5 & 61.65 & Good water & Unsuitable: WQI $>300$ \\
BH-6 & 70.85 & Good water & \\
BH-7 & 60.04 & Good water & \\
BH-8 & 82.81 & Good water & \\
BH-9 & 114.86 & Poor water & \\
BH-10 & 71.98 & Good water & \\
BH-11 & 64.16 & Good water & \\
BH-12 & 120.30 & Poor water & \\
BH-13 & 116.54 & Poor water & \\
BH-14 & 117.42 & Poor water & \\
\hline
\end{tabular}

\section{Piper diagrams}

Majority of the critical issues associated with hydrogeochemical of the groundwater have often been evaluated by plotting the percentage concentrations of major cations and anions in the meq/L in the Piper (1944) trilinear diagram. In this graphical presentation, there are three distinct fields such as two triangular fields at the bottom and one diamondshaped field at the top. The cations are represented as percentages of total cations in meq/l plot on the left side triangle and the anions are also plotted in the right-side triangle. The centrally located diamond-shaped field on the upper side of the two triangular fields to plot an overall chemical quality of groundwater. In these regards, the similarities and differences between several groundwater samples can be exposed from the trilinear due to water of analogous qualities would tend to plot together as groups in the diamond- shaped field at the top. It, therefore, in this graphical representation, separate groundwater qualities can be categorized rapidly by their plotting in specific areas of the diamond field. Analytical results which were obtained from the groundwater samples have been plotted on Piper trilinear diagram using aquachem software to evaluate the spatial distribution of hydrochemical changes in the study area.

The Piper trilinear diagram of the groundwaters is presented in Fig. 8. The diamond-shaped field of the Piper diagram is split into four classes as Mixed $\mathrm{Ca}-\mathrm{Na}-\mathrm{HCO}_{3}$ type, $\mathrm{Na}-\mathrm{Cl}$ type, $\mathrm{Na}-\mathrm{HCO}_{3}$ type, and $\mathrm{Ca}-\mathrm{HCO}_{3}$ type (Fig. 8). On the basis of the Piper diagram results, the majority of the samples in the study area fall in the category of $\mathrm{Ca}-\mathrm{HCO}_{3}$ type which showed sufficient recharge from fresh water. However, some of the samples fall in Mixed $\mathrm{Ca}-\mathrm{Mg}-\mathrm{Cl}$ type and some samples are also characterized mixed $\mathrm{Ca}-\mathrm{Na}-\mathrm{HCO}_{3}$ type according to their order of their dominance. Mixed fields of $\mathrm{Ca}-\mathrm{HCO}_{3}$ and $\mathrm{Ca}-\mathrm{Na}-\mathrm{HCO}_{3}$ in the piper diagram are suggestive of anthropogenic influences and irrigation return flow (Piper 1944). It is obviously evident from the plot that the majority of the samples, therefore, are alkaline earth metals $\left(\mathrm{Ca}^{2+}\right.$ and $\left.\mathrm{Mg}^{2+}\right)$ significantly exceed the alkalis $\left(\mathrm{Na}^{+}\right.$and $\left.\mathrm{K}^{+}\right)$and weak acids $\left(\mathrm{HCO}_{3}{ }^{-}\right.$and $\left.\mathrm{CO}_{3}{ }^{2-}\right)$ dominated strong acids $\left(\mathrm{Cl}^{-}\right.$and $\left.\mathrm{SO}_{4}{ }^{2-}\right)$. Some samples showed mixed character with composition fluctuating from mixed alkali bicarbonate to alkali bicarbonate calcium chloride type. Under this consideration, the alkaline earths had a higher concentration than bicarbonate in the study area, which designated exchange of $\mathrm{Na}^{+}$ion from the alkaline earths and the water as base exchanged hardened water.

\section{Gibbs diagram}

The chemical components of the groundwater are changed significantly by the influences of weathering and the respective aquifer lithologies. The Gibbs diagram is often applied

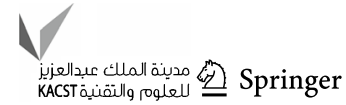




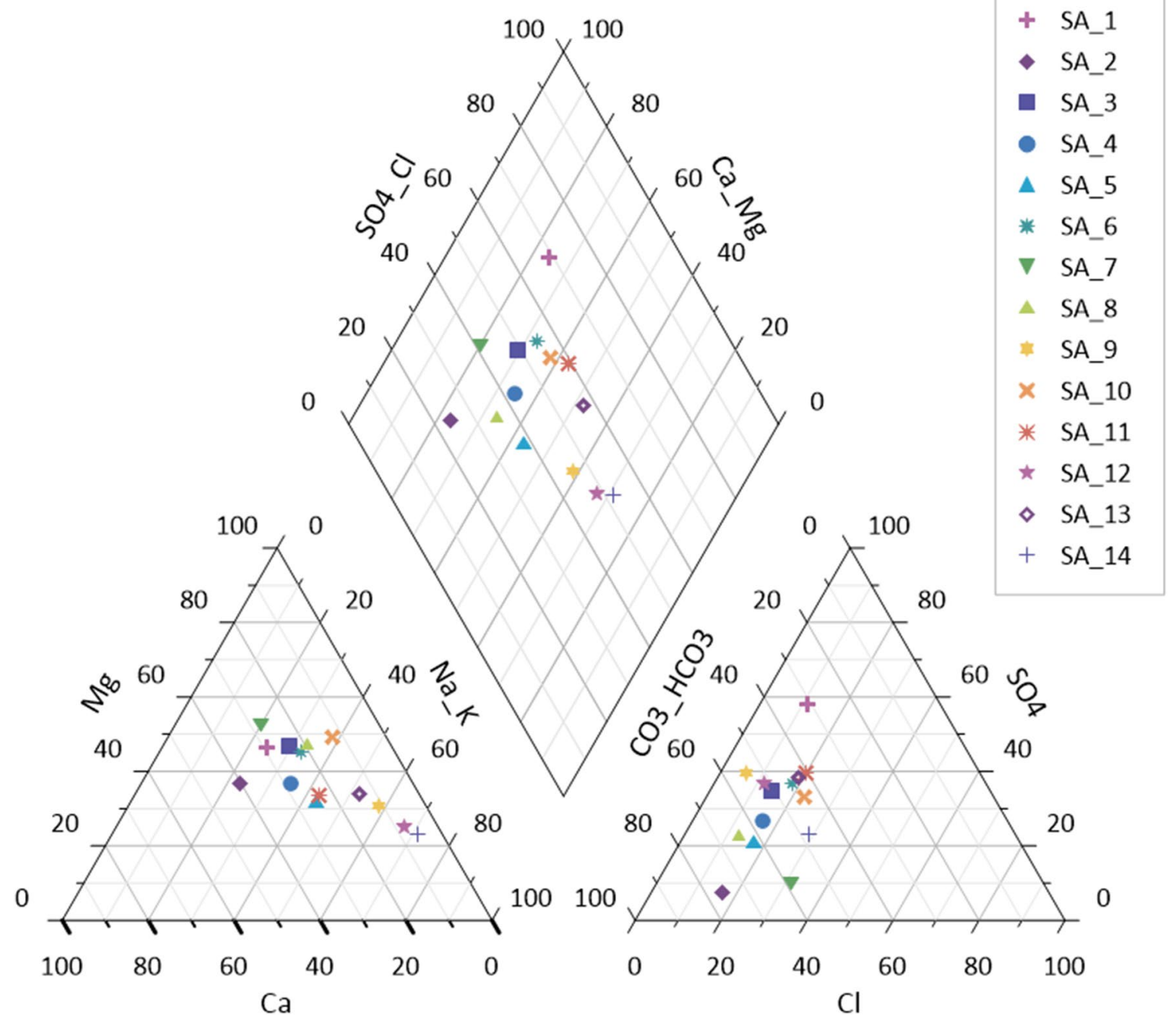

Fig. 8 Piper trilinear diagram for hydrogeochemical facies of study area groundwater samples

to establish the relationship of water composition and aquifer lithological characteristics Gibbs (1970), Eqs. 5 and 6). The Gibbs diagram provides three different fields on the natural mechanics governing quality of the groundwater namely precipitation dominance, evaporation dominance and rock- water interaction dominance which indicates the information on the likely cause of that resulting hydrochemistry of water (Fig. 9). The Gibbs plots in which TDS versus $\mathrm{Na}^{+}+\mathrm{K}+/\left(\mathrm{Na}^{+}+\mathrm{K}^{+}+\mathrm{Ca}^{+2}\right)$ for cations and TDS versus $\mathrm{Cl}^{-} /\left(\mathrm{Cl}^{-}+\mathrm{HCO}_{3}{ }^{-}\right)$for anion was drawn to illustrate the quality of the groundwater assessment and impact of host rock on groundwater chemistry. Based on the Gibbs fields (Fig. 9), the predominant samples of the study area fall in the rock-water interaction dominance and evaporation dominance field of the Gibbs diagram. The rock-water interaction dominance field designates the interface between rock chemistry and the chemistry of the percolation waters under the subsurface. However, few samples fall near the evaporation dominant zone in the same plot.

Gibbs ratio $I($ for cation $)=\frac{N a^{+}+K^{+}}{\left(N a^{+}+K^{+}+C a^{+2}\right)}$

Gibbs ratio $I I($ for anion $)=\frac{\mathrm{Cl}^{-}}{\left(\mathrm{Cl}^{-}+\mathrm{HCO}_{3}^{-}\right)}$

where all the ionic concentrations are expressed in meq/l.

\section{Sodium percentage $(\% \mathrm{Na})$}

The sodium percentage $(\% \mathrm{Na})$ is often used as a parameter to evaluate suitability of quality groundwater for irrigation purposes Wilcox (1955). High sodium concentration in the groundwater poses undesirable effects because the reaction 


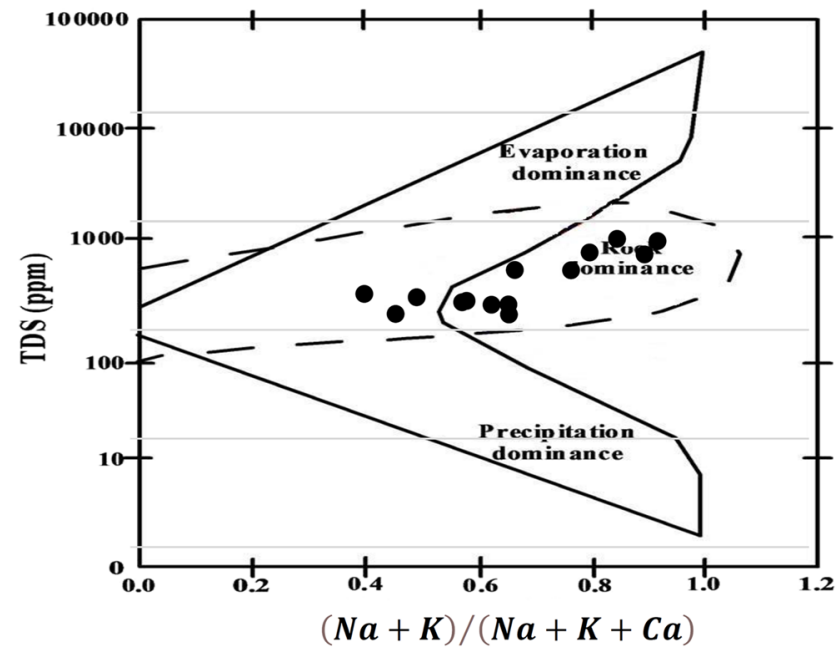

Fig. 9 Gibbs diagram for controlling factor of groundwater quality

of $\mathrm{Na}$ with the soil can reduce soil permeability and also little support or no plant growth. The percent sodium is computed with respect to relative proportions of cations present in water, where the concentrations of ions are expressed in meq/L, using the following formula:

$\% \mathrm{Na}=\frac{(\mathrm{Na}+\mathrm{K}) \times 100}{\{(\mathrm{Ca}+\mathrm{Mg}+\mathrm{Na}+\mathrm{K})\}}(m e q / l)$

In general, the percentage sodium should not exceed $60 \%$ for agricultural irrigation waters. Table 8 demonstrates that the $\mathrm{Na} \%$ of samples in the study area ranged from 20.24 to $71.04 \%$ with an average of $40.84 \%$, which indicated that the samples fall under the class of excellent to permissible except sample BHs-9, 12 and 14 for irrigation purpose. Analytical results were plotted on the Wilcox diagram Wilcox (1955) for the classification of groundwater samples in the study area for irrigation, wherein EC was plotted against sodium percent (Fig. 10). In the examination period, it was observed that $78.56 \%$ of water samples fall within excellent to permissible classes and the remaining $21.42 \%$ fall under

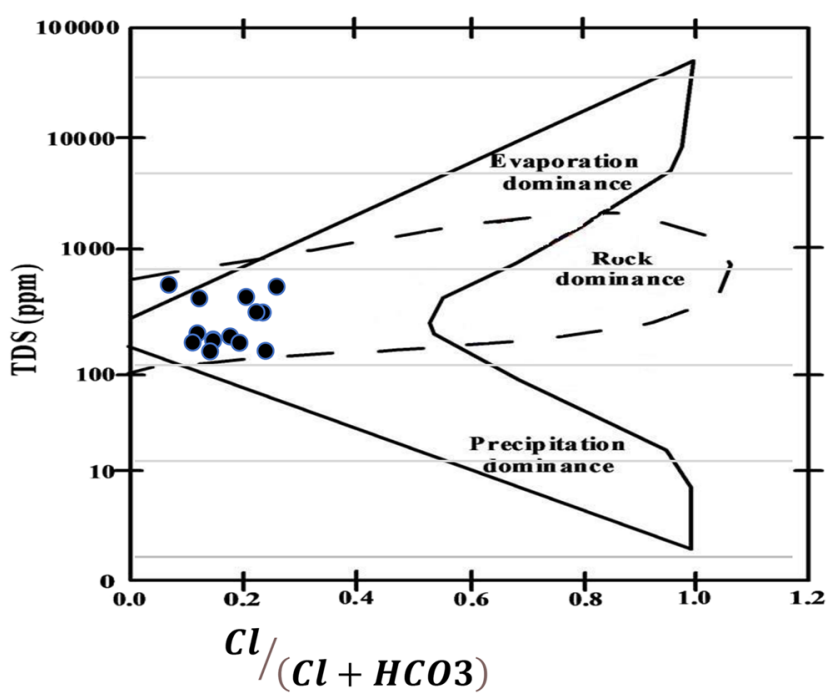

doubtful class (Table 8). It might be due to the recharge in rainy season may improve the irrigation water quality.

\section{Sodium adsorption ratio (SAR)}

Sodium adsorption ratio (SAR) is one of the features that generally need to be measured to evaluate suitability of groundwater for usage in agricultural irrigation. The application of groundwater with a high content of sodium for irrigation purposes could increase the exchange of sodium content of the soil and it thus can decrease the soil permeability and soil structure (Todd 1980). The irrigation using water with high SAR values may need soil amendments to avoid longterm harm to the soil due most likely the sodium in the water can displace the calcium and magnesium in the soil. It may also lead to decrease infiltration and permeability of the soil to water that may pose harm for crop production. SAR is a measure of main alkaline and earth alkaline cations present in the water to crops and it is given as:
Table 8 Classification of groundwater based on $\mathrm{Na} \%$ (Wilcox 1955)

\begin{tabular}{lllll}
\hline Water quality & Sodium $(\%)$ & Sample numbers & $\begin{array}{l}\text { Number of sam- } \\
\text { ples }\end{array}$ & $\begin{array}{l}\text { Percentage } \\
\text { of samples }\end{array}$ \\
\hline Excellent & $<20$ & 2 & 1 & 7.14 \\
Good & $20-40$ & $1,3,4,6,7,8,10$ & 7 & 50 \\
Permissible & $40-60$ & 5,11, and 13 & 3 & 21.42 \\
Doubtful & $60-80$ & 9,12 and 14 & 3 & 21.42 \\
Unsuitable & $>80$ & & & 0 \\
Total & & & 14 & 100 \\
\hline
\end{tabular}


Fig. 10 Classification of irrigation waters based on Wilcox diagram

$$
\operatorname{SAR}=\frac{\mathrm{Na}^{+}}{\sqrt{\frac{1}{2}\left(\mathrm{Ca}^{+}+\mathrm{Mg}^{+}\right)}}
$$

where $\mathrm{Na}, \mathrm{Ca}$, and $\mathrm{Mg}$ concentrations are expressed in milliequivalents/liter.

The irrigation water quality classification results are shown in Table 9. USSL (1954). The computed value of SAR in the study area was observed within 0.5-5.5 with an average of 2.08 (Table 9). SAR values of all samples are found in the range of excellent category, which is to be suitable for irrigation purposes. It is indicating that no alkali hazard is expected to the crops. If the value of SAR

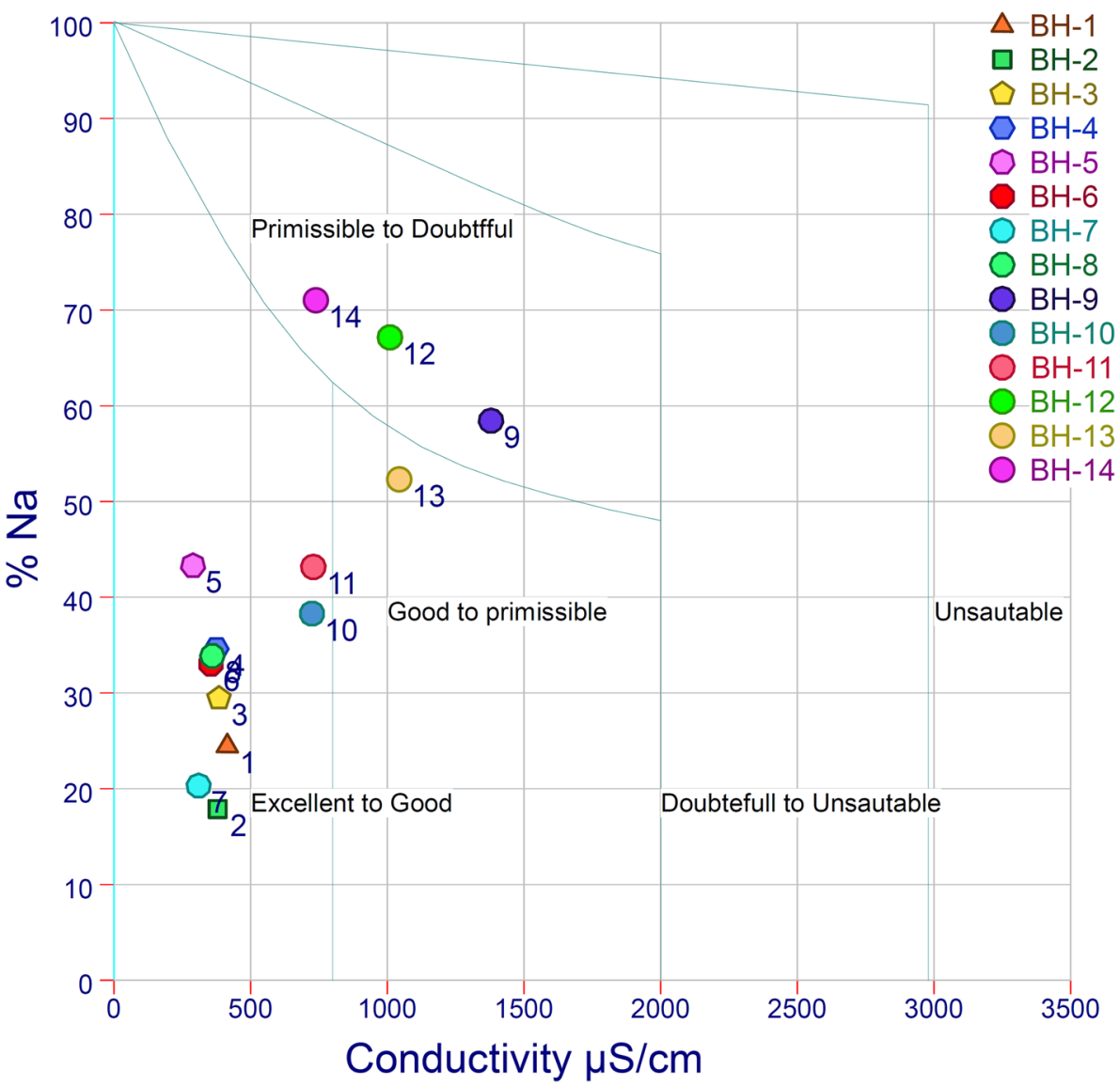

is within 6 to 9 , the irrigation water will cause permeability problems on shrinking and swelling types of clayey soils (USSL 1954).

US Salinity Laboratory diagram (Saleh et al. 1999) was used for rating irrigation waters, in which the SAR is plotted against EC. The SAR values plotted on the US salinity diagram indicated that 6 samples (42.86\%) fall in C3-S1 (high salinity-low sodium type), which can be used for irrigation in almost all types of soil with little danger of exchangeable sodium. About 11 (78.57\%) samples fall in C2-S1 (moderate salinity and low sodium water), and thus it can be used for irrigation on all types of soil (Fig. 11). However, the samples fall in $\mathrm{C} 2-\mathrm{S} 1$ for which the necessary requisites to be applied
Table 9 Groundwater sample of the study area based on the SAR classification

\begin{tabular}{lllll}
\hline Classification & SAR/EC & Sample numbers & $\begin{array}{l}\text { Number of } \\
\text { samples }\end{array}$ & \% of samples \\
\hline C3-S1 & SAR low & $6-14$ & 6 & 42.86 \\
EC medium-high 2 & & & \\
C2-S1 & SAR medium & & & \\
EC medium-high & & 8 & 57.14 \\
Total & SAR low & $1-8$ & & 100 \\
\hline
\end{tabular}


Fig. 11 USSL diagram for irrigation water quality classification (USSL Diagram 1954)

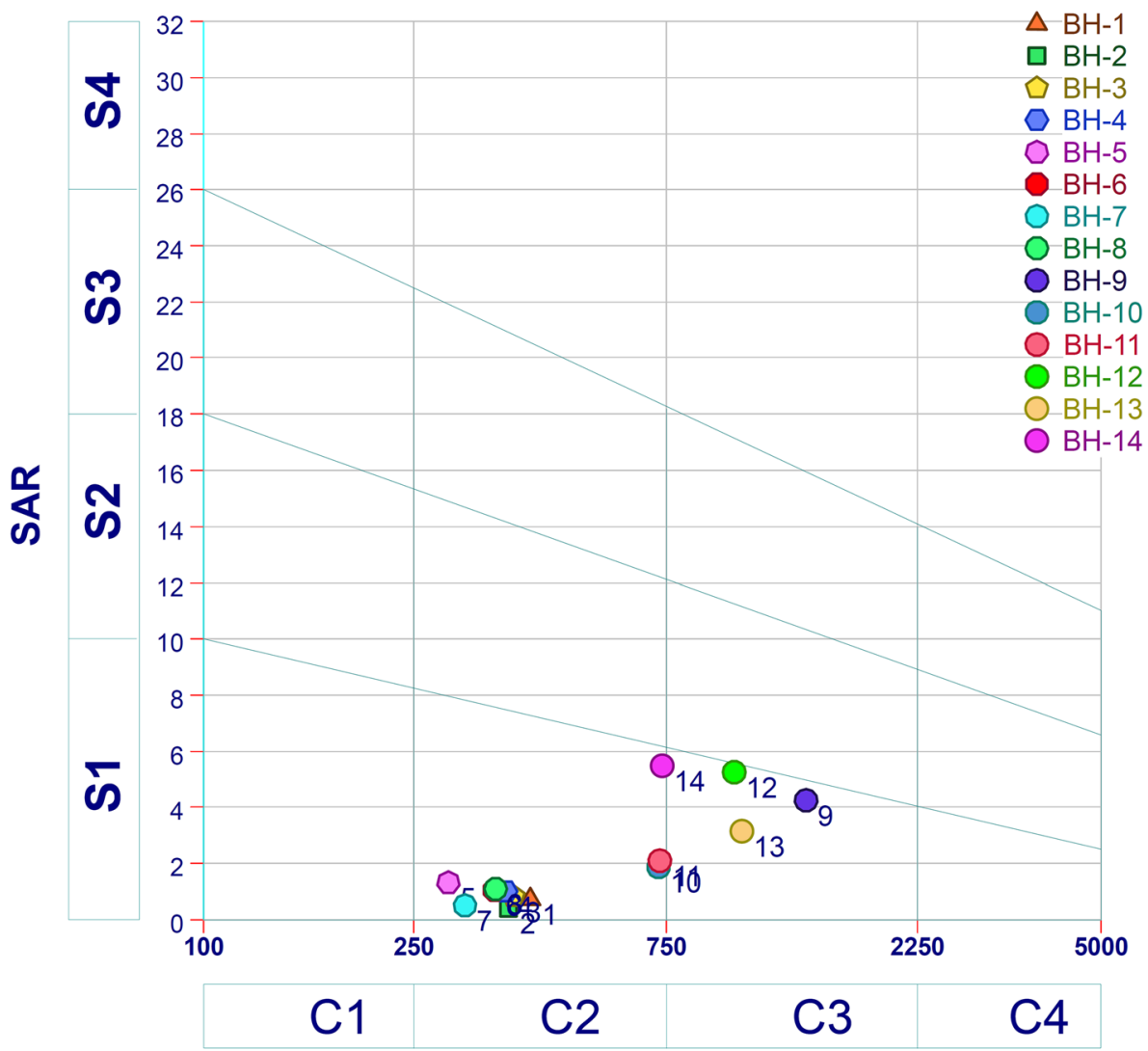

Conductivité en $\mu \mathrm{S} / \mathrm{cm}$ for irrigation is that the soil should encompass through moderate leaching.

\section{The residual sodium carbonate (RSC) index}

In the present study, the alkalinity hazard of irrigation water for soil was measured by the residual sodium carbonate (RSC) index. The RSC index is often used to assess the suitability of agricultural irrigation water in clay soils which have a high cation exchange capacity. The presence of higher dissolved sodium in comparison with dissolved calcium and magnesium in irrigation water cause clay soil swells or undergoes dispersion which can lead to diminishing drastically its infiltration capacity. The RSC is expressed in meq/L and its value should not be higher than 1 and most of the time the most preferable value to considering the water for irrigation consumption is less than +0.5 . The RSC index in the study is computed using:

$\mathrm{RSC}$ index $=\left[\mathrm{HCO}_{3}+\mathrm{CO}_{3}\right]-[\mathrm{Ca}+\mathrm{Mg}]$

$\mathrm{RSC}$ index $=\mathrm{HCO}_{3} / 61+\mathrm{CO}_{3 / 30}-\mathrm{Ca} / 20-\mathrm{Mg} / 12$

The RSC values in the study area were computed and compared with the RSC classification presented in
Table 10. It is observed that BH 11 and 13 fall in doubtful to unsuitable quality which show that water unsafe for irrigation purpose. However, the remaining samples fall within the safe quality classes for irrigation purposes. The continued usage of water with high RSC value would result in burning of leaves of plants and also significant impact on crop yields. Further, irrigation with $\mathrm{RSC}>2.5$ groundwater in the fine textured soil may cause the growth of alkali soil.

Table 10 Groundwater sample of the study area based on the RSC classification

\begin{tabular}{lllll}
\hline $\begin{array}{l}\text { RSC } \\
(\mathrm{meq} / \mathrm{L})\end{array}$ & $\begin{array}{l}\text { Classifica- } \\
\text { tion }\end{array}$ & $\begin{array}{l}\text { Sample } \\
\text { numbers }\end{array}$ & $\begin{array}{l}\text { Number } \\
\text { of sam- } \\
\text { ples }\end{array}$ & \% of samples \\
\hline$<1.25$ & Good & $\begin{array}{c}1-10,12 \text { and } \\
14\end{array}$ & 12 & 85.71 \\
$1.25-2.5$ & Doubtful & 11 & 1 & 7.14 \\
$>2.5$ & Unsuitable & 13 & 1 & 7.14 \\
Total & & & 14 & 100 \\
\hline
\end{tabular}




\section{Permeability index (PI)}

The soil permeability (PI) is often influenced by long-term irrigation water influenced by $\mathrm{Na}^{+}, \mathrm{Ca}^{2+}, \mathrm{Mg}^{2+}$ and $\mathrm{HCO}_{3}^{-}$ contents of the soil. PI is a vital parameter to evaluate the quality of irrigation water in association with the soil for improvement in agriculture and is expressed in meq/l. PI value is computed by using the following formula:

$P I=\frac{\left(\mathrm{Na}^{+} \sqrt{\mathrm{HCO}_{3}^{-}}\right) \times 100}{\left(\mathrm{Ca}^{+2}+\mathrm{Mg}^{+2}+\mathrm{Na}^{+}\right)}$

The computed PI value in the study area varies from 27.68 to 197.03 with an average value of about 88.03 which shows the groundwater quality was suitable for irrigation. WHO (2017) had suggested a criterion for evaluating the suitability of groundwater for irrigation based on the permeability index (PI). A classification of samples based on the PI was found as $90.9 \%$ of the samples fall under the class $3(<75 \%)$. The class 3 water is unsuitable with $25 \%$ of maximum permeability. Based on PI values, $90.9 \%$ of the samples belong to the class I category of WHO (1989) (ranged from 25 to $75 \%$ ) and only $9.1 \%$ falls under class II (PI ranged between 25 and 75\%). Thus, according to PI the groundwater samples of the study area have no permeability and infiltration problems.

\section{Conclusion and recommendation}

In this study, the groundwater hydrochemistry status was examined and mapped its spatial distribution for evaluating the groundwater suitability, as major resources of drinking and irrigation purposes at Arba Minch town, in AbayaChemo sub-basin of the Great Rift Valley of Ethiopia. Based on the main finding of results in the study, the following conclusions are drawn herein:

The results of hydrochemical analyses revealed that the present status of groundwaters in Arba Minch town is safe and suitable for drinking and irrigation purposes. However, excess concentrations of hardness, chloride, Nitrate and TDS at very few locations which make some groundwaters were undesirable for drinking uses. For such areas, adequate preconditions are required because the dynamic urbanization development in the region is the main factor for the groundwater quality to be deteriorated in the future. Thus, the northeastern part of the study area needs some serious monitoring to protect the groundwater quality deterioration from the threats of contamination from the exhaustive agriculture and uncontrol waste dumping points.
The water quality index of most of samples in the study area is classified as excellent (7\%) and good (64\%) class, and none of them were fall as poor, very poor and unsuitable for drinking class. The dominance of hydrochemical facies of groundwater in the study area is $\mathrm{Ca}-\mathrm{Mg}-\mathrm{HCO}_{3}$ type with some minor hydrochemical facies of $\mathrm{Ca}-\mathrm{Mg}-$ $\mathrm{Cl} ; \mathrm{Na}-\mathrm{HCO}_{3}-\mathrm{Cl}$ facies, and $\mathrm{Na}-\mathrm{Cl}^{-}$facies. The rockwater interaction and evaporation are two main dominating processes that control the chemical composition of groundwater in the study area.

Most of samples are found as a good class for irrigation use and suitable for irrigation. About $87 \%$ of water samples fall within high salinity and low sodium hazards (C3-S1), which needs good drainage. SAR values varied within 0.53 to 6.02 , which are clearly less than 10 , representing that the groundwater is suitable for irrigation.

The study can be concluded that quality of the groundwater samples was in general suitable for drinking and irrigation purposes. However, urbanization and improper waste disposal along with extensive agricultural activities have severely affected quality of the groundwater specifically on the northwestern part of Arba Minch town. This study recommended that the groundwater resources in the study area should be properly managed due to the dynamic urban development and uncontrol waste disposal that happens in these provinces can deteriorate the quality of groundwater in future.

Funding No specific funding was received for this work.

\section{Declarations}

Conflict of interest The authors declare that they have no conflict of interest.

Open Access This article is licensed under a Creative Commons Attribution 4.0 International License, which permits use, sharing, adaptation, distribution and reproduction in any medium or format, as long as you give appropriate credit to the original author(s) and the source, provide a link to the Creative Commons licence, and indicate if changes were made. The images or other third party material in this article are included in the article's Creative Commons licence, unless indicated otherwise in a credit line to the material. If material is not included in the article's Creative Commons licence and your intended use is not permitted by statutory regulation or exceeds the permitted use, you will need to obtain permission directly from the copyright holder. To view a copy of this licence, visit http://creativecommons.org/licenses/by/4.0/.

\section{References}

Abbasnia A, Yousefi N, Mahvi AH et al (2019) Evaluation of groundwater quality using water quality index and its suitability for 
assessing water for drinking and irrigation purposes: Case study of Sistan and Baluchistan province (Iran). Hum Ecol Risk Assess 25(4):988-1005. https://doi.org/10.1080/10807039.2018.1458596

Abd El-Aziz SH (2017) Evaluation of groundwater quality for drinking and irrigation purposes in the north-western area of Libya (Aligeelat). Environ Earth Sci 76(4):1-17. https://doi.org/10.1007/ s12665-017-6421-3

Adimalla N, Li P, Venkatayogi S (2018) Hydrogeochemical evaluation of groundwater quality for drinking and irrigation purposes and integrated interpretation with water quality index studies. Environ Process 5(2):363-383. https://doi.org/10.1007/ s40710-018-0297-4

Adimalla N, Dhakate R, Kasarla A, Taloor AK (2020) Appraisal of groundwater quality for drinking and irrigation purposes in Central Telangana. India Groundw Sustain Dev 10:100334. https:// doi.org/10.1016/j.gsd.2020.100334

Ahamad A, Raju NJ, Madhav S, Gossel W, Wycisk P (2019) Impact of non-engineered Bhalswa landfill on groundwater from Quaternary alluvium in Yamuna flood plain and potential human health risk, New Delhi, India. Quat Int 507:352-369. https://doi.org/10. 1016/j.quaint.2018.06.011

APHA (2005) Standard Methods for the Examination of Water and Wastewater, 21st edn. American Public Health Association

Bawoke GT, Anteneh ZL (2020) Spatial assessment and appraisal of groundwater suitability for drinking consumption in Andasa watershed using water quality index (WQI) and GIS techniques: Blue Nile Basin. Northwestern Ethiopia Cogent Eng 7(1):1748950. https://doi.org/10.1080/23311916.2020.1748950

Berhanu B, Seleshi Y, Melesse AM (2014) Surface water and groundwater resources of Ethiopia: potentials and challenges of water resources development. Nile River Basin. Springer, pp 97-117

Beyene G, Aberra D, Fufa F (2019) Evaluation of the suitability of groundwater for drinking and irrigation purposes in Jimma Zone of Oromia. Ethiopia Groundw Sustain Dev 9:100216. https://doi. org/10.1016/j.gsd.2019.100216

Bhunia GS, Keshavarzi A, Shit PK, Omran ESE, Bagherzadeh A (2018) Evaluation of groundwater quality and its suitability for drinking and irrigation using GIS and geostatistics techniques in semiarid region of Neyshabur. Iran Appl Water Sci 8(6):1-16. https://doi.org/10.1007/s13201-018-0795-6

Boateng TK, Opoku F, Acquaah SO, Akoto O (2016) Groundwater quality assessment using statistical approach and water quality index in Ejisu-Juaben Municipality. Ghana Environ Earth Sci 75(6):489. https://doi.org/10.1007/s12665-015-5105-0

Bordalo AA, Teixeira R, Wiebe WJ (2006) A Water quality index applied to an international shared river basin: the case of Douro River. Environ Manag 38:910-920. https://doi.org/10.1007/ s00267-004-0037-6

Brown RM, McClelland NI, Deininger RA, Tozer RG (1970) A water quality index - do we dare? Water SewWorks 117:339-343

CSA (2007) Ethiopia Office of the Population, \& Housing Census Commission. Summary and statistical report of the (2007) population and housing census: population size by age and sex. Federal Democratic Republic of Ethiopia, Population Census Commission

Davis SN, DeWiest RJ (1966) Hydrogeology. Wiley

Domenico PA, Schwartz FW (1990) Physical and chemical hydrogeology. John Wiely and Sons

ES, Ethiopian Standard, (2003) National Drinking water-specification, 2nd edn. Quality and Standards Authority of Ethiopia

Esmeray E, Gökcekli C (2020) Assessment of groundwater quality for drinking and irrigation purposes in Karabuk province. Turkey Environ Earth Sci 79(13):1-17. https://doi.org/10.1007/ s12665-020-09074-4

Freeze RA, Cherry JA (1979) Groundwater. Prentice Hall
Gibbs RJ (1970) Mechanisms Controlling World Water Chemistry. Sci 170(3962):1088-1090. https://doi.org/10.1126/science.170. 3962.1088

Gupta PK (2020) Pollution load on Indian soil-water systems and associated health hazards: a review. J Environ Eng 146(5):03120004. https://doi.org/10.1061/(ASCE)EE.1943-7870.0001693

Horton RK (1965) An index number system for rating water quality. J Water Pollut Control Fed 37(3):300-306

Ismail AH, Hassan G, Sarhan AH (2020) Hydrochemistry of shallow groundwater and its assessment for drinking and irrigation purposes in Tarmiah district, Baghdad Governorate. Iraq Groundw Sustain Dev 10:100300. https://doi.org/10.1016/j.gsd.2019. 100300

Lakshmanan E, Kannan K, Senthil Kumar M (2003) Major ion chemistry and identification of hydrogeochemical process of groundwater in part of Kancheepuram district, Tamilnadu, India. J Environ Geosci 10:157-166. https://doi.org/10.1306/eg.0820303011

Mahaqi A, Moheghi MM, Mehiqi M, Moheghy MA (2018) Hydrogeochemical characteristics and groundwater quality assessment for drinking and irrigation purposes in the Mazar-i-Sharif city. North Afghanistan Appl Water Sci 8(5):1-10. https://doi.org/10.1007/ s13201-018-0768-9

Mahlknecht J, Merchán D, Rosner M, Meixner A, Ledesma-Ruiz R (2017) Assessing seawater intrusion in an arid coastal aquifer under high anthropogenic influence using major constituents, $\mathrm{Sr}$ and B isotopes in groundwater. Sci Total Environ 587:282-295. https://doi.org/10.1016/j.scitotenv.2017.02.137

Mallick J, Kumar A, Almesfer MK, Alsubih M, Singh CK, Ahmed M, Khan RA (2021) An index-based approach to assess groundwater quality for drinking and irrigation in Asir region of Saudi Arabia. Arab J Geosci 14(3):1-17. https://doi.org/10.1007/ s12517-021-06506-8

Mishra S, Tiwary D, Ohri A, Agnihotri AK (2018) Assessment of groundwater quality using WQI and GIS near the Karsara municipal landfill site, Varanasi. India Arab J Geosci 11(11):252. https:// doi.org/10.1007/s12517-018-3604-5

Piper AM (1944) A graphical procedure in the geochemical interpretation of water analyses. Geophys Union Transa 25(6):914. https:// doi.org/10.1029/TR025i006p00914

Ponsadailakshmi S, Sankari SG, Prasanna SM, Madhurambal G (2018) Evaluation of water quality suitability for drinking using drinking water quality index in Nagapattinam district, Tamil Nadu in Southern India. Groundw Sustain Dev 6:43-49. https://doi.org/ 10.1016/j.gsd.2017.10.005

Rana R, Ganguly R, Gupta AK (2018) Indexing method for assessment of pollution potential of leachate from non-engineered landfill sites and its effect on ground water quality. Environ Monit Assess 190(1):46.

Rawat K, Pradhan S, Tripathi V, Jeyakumar L, Singh SK (2019) Statistical approach to evaluate groundwater contamination for drinking and irrigation suitability. Groundw Sustain Dev. https://doi.org/ 10.1016/j.gsd.2019.100251

Roy A, Keesari T, Mohokar H, Sinha UK, Bitra S (2018) Assessment of groundwater quality in hard rock aquifer of central Telangana state for drinking and agriculture purposes. Appl Water Sci 8(5):1-18. https://doi.org/10.1007/s13201-018-0761-3

Saleem M, Hussain A, Mahmood G (2016) Analysis of groundwater quality using water quality index: a case study of greater Noida (Region), Uttar Pradesh (UP). India Cogent Eng 3(1):1237927. https://doi.org/10.1080/23311916.2016.1237927

Saleh A, Al-Ruwaih F, Shehata M (1999) Hydrogeochemical processes operating within the main aquifers of Kuwait. J Arid Environ 42(3):195-209. https://doi.org/10.1006/jare.1999.0511

Stumm W, Morgan JJ (1981) Aquatic chemistry. Wiley Interscience Todd DK (1980) Groundwater Hydrology. Wiley

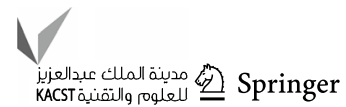


Tomas D, Čurlin M, Marić AS (2017) Assessing the surface water status in Pannonian ecoregion by the water quality index model. Ecol Indic 79:182-190. https://doi.org/10.1016/j.ecolind.2017.04.033

USSL (US Salinity Laboratory) (1954) Diagnosis and improvement of saline and alkali soils. U.S. Department of Agriculture Hand Book, No. 60, p.160.

Verma A, Yadav BK, Singh NB (2020) Hydrochemical monitoring of groundwater quality for drinking and irrigation use in Rapti Basin. Appl Sci 2(3):1-15. https://doi.org/10.1007/s42452-020-2267-5

WHO (2017) Guidelines for Drinking-Water Quality. World Health Organization

Wilcox L (1955) Classification and use of irrigation waters. US Department of Agriculture

Yousefi H, Zahedi S, Niksokhan MH (2018) Modifying the analysis made by water quality index using multi-criteria decision-making methods. J Afr Earth Sci 138:309-318. https://doi.org/10.1016/j. jafrearsci.2017.11.019
Zhou Y, Li P, Xue L, Dong Z, Li D (2020) Solute geochemistry and groundwater quality for drinking and irrigation purposes: a case study in Xinle City. North China Geochem 80(4):125609. https:// doi.org/10.1016/j.chemer.2020.125609

Zhou Y, Li P, Chen M, Dong Z, Lu C (2021) Groundwater quality for potable and irrigation uses and associated health risk in southern part of Gu' an County. North China Plain Environ Geochem Health 43(2):813-835. https://doi.org/10.1007/s10653-020-00553-y

Publisher's Note Springer Nature remains neutral with regard to jurisdictional claims in published maps and institutional affiliations. 